1 Scoping Review of Existing Stroke Guidelines; Argument for a Value-Added Change

Scoping Review of Existing Stroke Guidelines; Argument for a Value-Added Change

Tissa Wijeratne ${ }^{\text {abc* } *}$ Carmela Sales ${ }^{\text {ab }}$ Mihajlo (Michael) Jakovljevic ${ }^{\mathrm{d}, \mathrm{e}}$, Leila Karimi ${ }^{\text {abf }}$

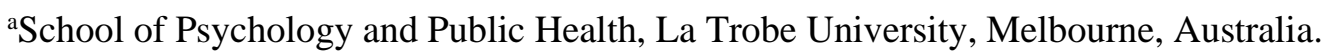

${ }^{\mathrm{b}}$ Head of Department of Neurology, Western Health \& University Melbourne, AIMSS, Level three, WHCRE, Sunshine Hospital, St Albans, 3021, Australia.

${ }^{\mathrm{c}}$ Department of Medicine, Faculty of Medicine, University of Rajarata, Saliyapura, Anuradhapura, Sri Lanka.

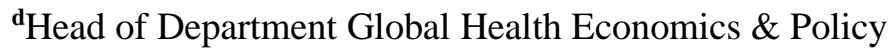

University of Kragujevac Faculty of Medical Sciences, SERBIA

e Professor, Institute of Comparative Economic Studies

Hosei University Faculty of Economics, Tokyo, JAPAN

${ }_{\mathrm{f}}^{\mathrm{F}}$ aculty of Social and Political Sciences, Tbilisi State University, Georgia

- Corresponding author:tissa.wijeratne@wh.org.au

Wijeratne et al, 2021 
2 Scoping Review of Existing Stroke Guidelines; Argument for a Value-Added Change

\begin{abstract}
:
Background and Purpose: Stroke represents one of the most important causes of morbidity ( eighty million patients with disabling of ongoing effects of stroke at a given time, globally) and mortality (the second leading cause of death) worldwide. Innovative systems biologybased approach is likely to increase the understanding of the underpinning of acute stroke promise to enhance stroke prevention, acute treatment, and neurorehabilitation. Recent growing body of evidence with shared pathobiology with COVID-19 and the critically important role of inflammation in the context of stroke points to far-reaching consequences of acute stroke, just as in the case of COVID-19 ( post-acute event issues as well as long term issues ).
\end{abstract}

So far, stroke typically defined by late-appearing disease manifestation by the range of stroke subtypes as defined by the WHO or American Stroke Association. This definition neglects the underlying pathobiological mechanisms such as low-grade chronic inflammation and already compromised vascular system. Diseases such as stroke is hardly a simple result of a single problem, but rather a complex cascade of pathobiological processes and interactions in a complex biochemical environment. The evidence of changes in innate immunity and adaptive immunity during the index event of acute stroke and recovery over next 3-12 months can be easily elicited with simple bedside blood tests such as neutrophil-lymphocyte ratio (NLR) with well over 300 published papers including several systematic reviews and meta-analyses confirming this. Global standard operating procedures (SOP) of stroke care dictated by the national and international stroke guidelines at present. It is imperative to explore the evidence of systems biology approach in current stroke guidelines. This is likely 


\section{Scoping Review of Existing Stroke Guidelines; Argument for a Value-Added Change}

to be a key turning point in managing stroke across the continuum (prevention, management of acute event and rehabilitation).

Methods: We systematically searched for guideline recommendation on the day-to-day use of peripheral inflammatory markers such as NLR published in the English language between January 1, 2005, and December 2020. Any other evidence of systems biology-based approach or recommendation was explored within the selected guidelines for this scoping review. Only the latest guideline per writing group was selected. Each guideline was analyzed independently by 2 to 4 authors to determine clinical scenarios explained/given, scientific evidence used, and recommendations presented in the context of systems biology.

Results: The scoping review found 3,830 (3830) titles with 119 guidelines from 46 countries included for this review ( Figure 1; PRISMA diagram). Stroke-related organizations wrote Sixty-five per cent of the guidelines while national ministries wrote a fewer number of guidelines. We were primarily interested in recommendations for acute management in AIS published in the English language. Fifteen eligible guidelines were identified from 15 different countries/regions. None of the guidelines recommended the routine use of peripheral markers of inflammation, such as NLR, among their acute assessment and management recommendations. None of the existing guidelines explored the systems biology approach to one of the most complex diseases affecting the human brain, stroke.

Conclusions: This systematic review has identified a significant evidence-practice gap in all existing national stroke guidelines published in English medium as of October 2020. These 
4 Scoping Review of Existing Stroke Guidelines; Argument for a Value-Added Change

guidelines included the only current "living stroke guidelines, Stroke Guidelines from Australia with a real opportunity to modernize the living stroke guidelines with systems biology approach and provide 2020 vision towards better stroke care globally.

Investigation of complex disease such as stroke is best served through a systems biology approach. One of the easiest places to start is simple blood tests such as total white cell count and NLR. Systems biology approach point us towards simple tools such immuneinflammatory index (SII), Sunshine Prognostic Score (SPS) which should pave the way for the stroke physician community address the challenges in systems biology approach in stroke care. These challenges include translating bench research to the bedside, managing big data ( continuous pulse, blood pressure, sleep, Oxygen saturation, progressive changes in NLR, SII, SPS, etc.). Working with an interdisciplinary team is also provide a distinct advantage.

\section{Introduction}

Evidence-based medicine calls for the utilization of widely available clinical guidelines especially for the management of common conditions which have an impact on mortality and morbidity such as acute ischemic stroke (AIS). The first of this kind was published in 1974 which was entitled 'Prologue to Guidelines for Stroke Care', a compendium of articles compiled by Neurologists on the management of cerebrovascular disease (1) It was not until more than 20 years later that the Cochrane Collaboration Stroke Review Group convened and initiated the task of constructing a systematic guideline for the management of acute stroke (2). 


\section{Scoping Review of Existing Stroke Guidelines; Argument for a Value-Added Change}

Clinical guidelines are essential tools to improve the quality of healthcare systems. Noncommunicable diseases (NCDs) and vascular ones in particular are lifetime complex chronic conditions, which are expensive to treat(3) and expose tremendous budget impact affecting entire financial sustainability of contemporary health systems (4). Factors which are crucial for a clinical guideline to be successfully crafted is team collaboration and multidisciplinary engagement $(5,6)$. Furthermore, these should be tailor-fitted to individual country needs, hence, the non-existence of a universally implemented guideline (6) . The use of tools to assess the quality of evidence also aids clinicians to interpret the recommendations according to the weight of evidence (7). Potential barriers to non-adherence include unfamiliarity, lack of agreement and outcome expectancy, as well as the significant impact of the precedent guideline (8) .

Perhaps one of the game-changers in the history of medicine is the development of clinical guidelines for the management of AIS. The wealth of data from clinical trials on reperfusion therapies paved the way for the American Heart Association (AHA) and the Canadian Stroke Consortium to publish their respective recommendations on the acute intervention of cerebrovascular ischemia $(9,10)$. Through time, various versions of clinical guidelines have also been published in different languages with the primary objective of implement ability according to the resources available in each country. While constructs behind these standard procedures are anchored on the same theory, some degree of variability still occurs(11). To date, there are no studies which specifically look at the differences in the clinical guidelines on acute ischemic stroke in a worldwide. It is in this light that this study was conceived by the first author (TW). 
6 Scoping Review of Existing Stroke Guidelines; Argument for a Value-Added Change

\section{Methodology}

The authors of this review used the Arksey and O’Malley methodology to identify and extract useful literature. The steps undertaken include (1) research question identification; (2) relevant literature identification;(3) screening and selection of relevant literature;(4) data charting; and (5) analyzing, summarizing, and reporting results.

MEDLINE, Cochrane and CINHAL databases were searched to identify useful keywords . Subsequently, the identified keywords were used to search the same databases for relevant studies. Literature were first screened at the title, and the abstract level then the full text articles.

Following search term were employed based on the PICO strategy. Topic= " country name" AND TOPIC="guideline" OR" clinical protocols" OR "recommendations" OR " standards" AND TOPIC $=$ stroke OR cerebrovascular disorder OR cerebrovascular accident.

Guideline repositories such as the National Guideline Clearinghouse, the Scottish Intercollegiate Guidelines Network (SIGN) and Professional stroke societies were also searched. Individual bibliographies were also manually searched. Studies were included if they met the following criteria: a) published after year 2000 b) guidelines on stroke and/or poststroke rehabilitation c) graded recommendations d) written in English. Titles and abstracts were initially screened (TW) and any full-text articles were further appraised (TW, CS). Any disagreement was adjudicated by an independent reviewer (LK). Guidelines which were updated in a modular format and published over separate papers were treated as one guideline. 
7 Scoping Review of Existing Stroke Guidelines; Argument for a Value-Added Change

\section{Results}

\section{Guideline characteristics}

Figure 1 shows the diagram on available stroke guidelines worldwide. Majority of the countries have no available published national guidelines while a number have guidelines but no graded recommendations. A significant majority also have guidelines published in their own language while 14 countries have their own published, graded, English clinical guidelines, with the one from the European Stroke Organization as a separate entity.

Figure 1

Acute Ischemic Stroke Guidelines Worldwide
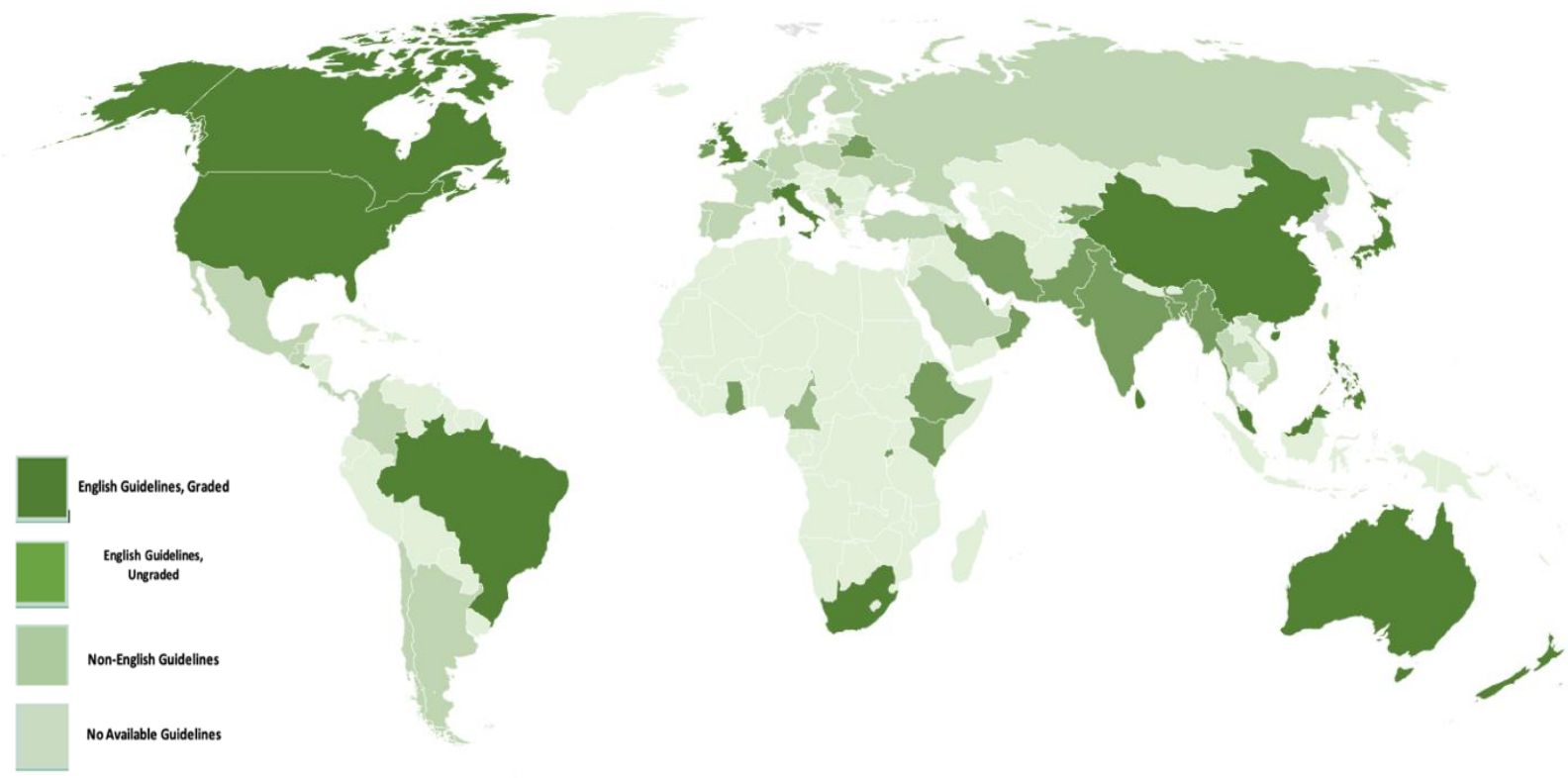

A total of 2897 titles were identified in the electronic search. Fourteen additional records were identified through other sources. After removal of duplicates and screening at the title level, 255 articles were further reviewed at the abstract level. Hundred and eighty-one papers were 
8 Scoping Review of Existing Stroke Guidelines; Argument for a Value-Added Change

thoroughly assessed by the two authors (TW and CS) for eligibility. A total of 15 guidelines were included in this scoping review. 


\section{Scoping Review of Existing Stroke Guidelines; Argument for a Value-Added Change}

Figure 2 : PRISMA Diagram

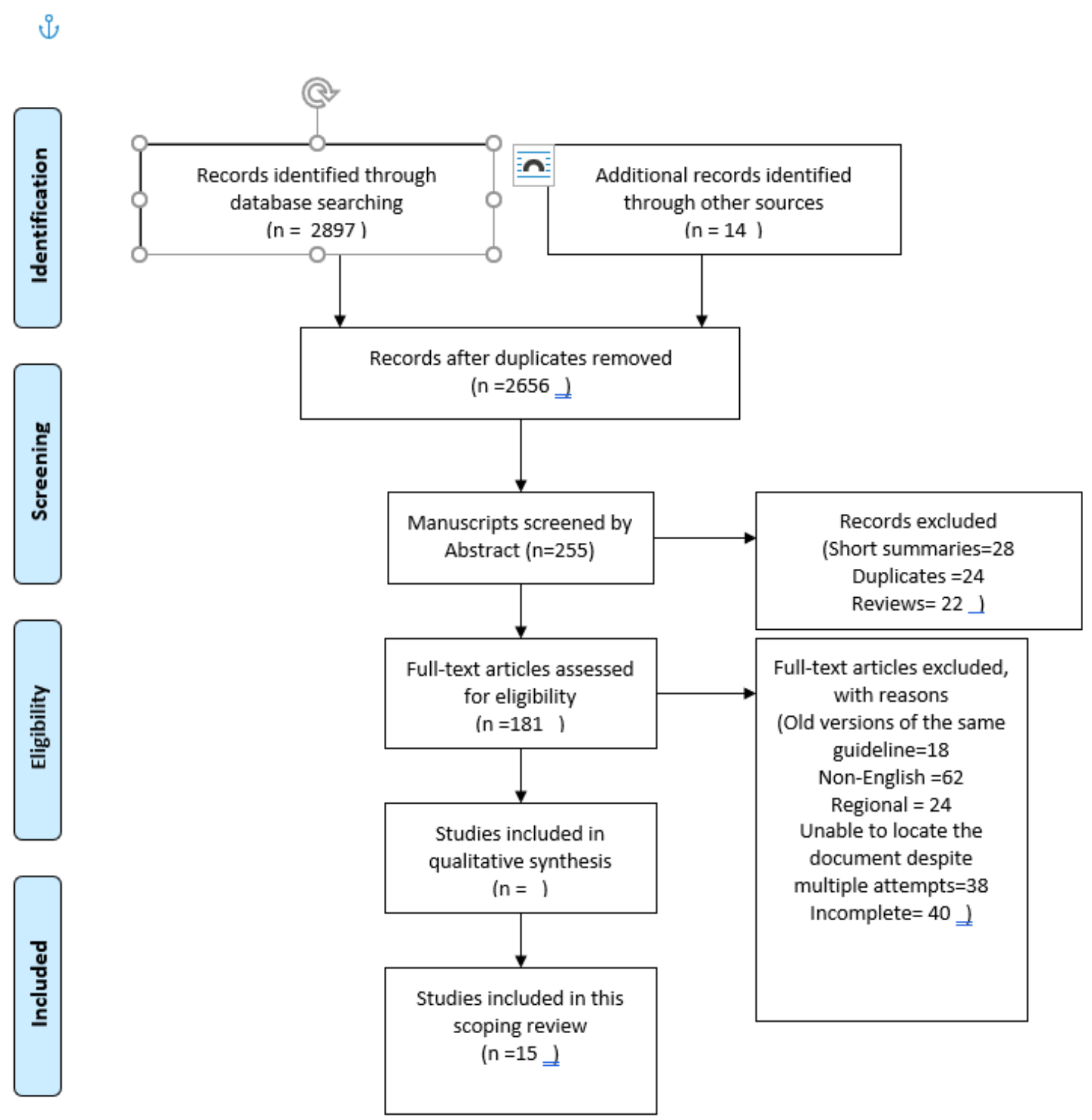

Table 1 outlines the characteristics of the 15 clinical guidelines included in this study while

Table 2 describes the recommendations of individual guidelines and the specific grades tagged on each guideline parameter . 
10 Scoping Review of Existing Stroke Guidelines; Argument for a Value-Added Change

Wijeratne et al, 2021 
11 Scoping Review of Existing Stroke Guidelines; Argument for a Value-Added Change

Table 1. Summary of Acute Ischemic Stroke Clinical Guidelines

\begin{tabular}{|c|c|c|c|}
\hline Country & Name of Guideline & $\begin{array}{l}\text { Year of First } \\
\text { Published } \\
\text { Version }\end{array}$ & Subsequent revisions \\
\hline $\begin{array}{l}\text { Australia/New } \\
\text { Zealand (12) }\end{array}$ & $\begin{array}{c}\text { Clinical Guidelines for Stroke } \\
\text { Management }\end{array}$ & 2007 & 2010,2019 \\
\hline Brazil (13) & $\begin{array}{c}\text { Guidelines for Acute Ischemic Stroke } \\
\text { Treatment }\end{array}$ & 2001 & 2012 \\
\hline Canada (14) & $\begin{array}{c}\text { Canadian Best Practice } \\
\text { Recommendations for Acute Stroke } \\
\text { Management }\end{array}$ & 1998 & $\begin{array}{c}2006,2008,2010 \\
2015,2018\end{array}$ \\
\hline China (15) & $\begin{array}{l}\text { The Chinese Stroke Association } \\
\text { scientific statement: intravenous } \\
\text { thrombolysis in acute ischaemic } \\
\text { stroke }\end{array}$ & 2012 & 2014,2017 \\
\hline ESO (16) & $\begin{array}{l}\text { European Stroke Organisation- } \\
\text { Karolinska Stroke Update }\end{array}$ & 2003 & $2015,2017,2019$ \\
\hline Italy (17) & $\begin{array}{c}\text { The Italian Guidelines for stroke } \\
\text { prevention }\end{array}$ & 2000 & \\
\hline
\end{tabular}


12 Scoping Review of Existing Stroke Guidelines; Argument for a Value-Added Change

\begin{tabular}{|c|c|c|c|}
\hline Japan (18) & $\begin{array}{c}\text { Japanese Guidelines for the } \\
\text { Management of Stroke }\end{array}$ & 2004 & 2009 \\
\hline Malaysia (19) & $\begin{array}{l}\text { Clinical Practice Guidelines, } \\
\text { Management of Ischemic Stroke }\end{array}$ & 2003 & 2006 \\
\hline Qatar (20) & $\begin{array}{l}\text { Clinical Guidelines for the State of } \\
\text { Qatar, the Diagnosis and } \\
\text { Management of Stroke and TIA }\end{array}$ & 2016 & \\
\hline Scotland (21) & $\begin{array}{l}\text { Management of patients with Stroke } \\
\text { and TIA: assessment, investigation, } \\
\text { immediate management and } \\
\text { secondary prevention }\end{array}$ & 2008 & \\
\hline Singapore (22) & $\begin{array}{l}\text { Stroke and TIA: assessment, } \\
\text { investigation, immediate } \\
\text { management and secondary } \\
\text { prevention }\end{array}$ & 2009 & 2011 \\
\hline $\begin{array}{l}\text { South Africa } \\
\text { (23) }\end{array}$ & $\begin{array}{l}\text { South African guideline for } \\
\text { management of ischaemic stroke and } \\
\text { transientischaemic attack 2010: A } \\
\text { guideline from the South African } \\
\text { Stroke Society(SASS) and the SASS } \\
\text { Writing Committee }\end{array}$ & 2000 & 2010 \\
\hline Sri Lanka (24) & $\begin{array}{c}\text { Clinical Practice Guidelines, } \\
\text { Management of Stroke }\end{array}$ & 2017 & \\
\hline
\end{tabular}


13 Scoping Review of Existing Stroke Guidelines; Argument for a Value-Added Change

\begin{tabular}{|c|c|c|c|}
\hline UK (25) & $\begin{array}{c}\text { National clinical guideline for stroke } \\
\text { of Patients With Acute }\end{array}$ & 2000 & 2016,2017 \\
& $\begin{array}{c}\text { Guidelines for the Early Management } \\
\text { Ischemic Stroke: 2019 Update to the } \\
2018 \text { Guidelines for the }\end{array}$ & $2007,2013,2015$, \\
ESA (26) & Early Management of Acute & & \\
\hline
\end{tabular}

\section{Regionalization and Adaptation from other clinical guidelines}

Most countries worldwide have no available published national guidelines. However, this does not translate to lack of systematic processes and workflows in the management of acute ischemic stroke. The European Stroke Organization has successfully implemented the ESO Stroke Guidelines which is being operationalized by countries in the European region (16). A unified approach is also being implemented in Australia and New Zealand as they both adapt the Australian Clinical Guideline for Stroke Management published in 2017 (27). More recently, the Middle East and North Africa Stroke and Interventional Neurotherapies Organization has also created a consolidated plan to manage stroke in the midst of the pandemic (28).

Most of the conceptualized guidelines have been adapted from existing ones, usually from high income countries (29). A systematic review comparing stroke clinical practice guidelines (CPGs) from low and high-income countries revealed that a degree of compromise in terms of the quality on the former (29). It is in this reason that in 2014, the World Stroke Organization 
14 Scoping Review of Existing Stroke Guidelines; Argument for a Value-Added Change

conceived the WSO Global Stroke Services Guideline and Action Plan (30). This initiative aims to aid country-level health authorities to set-up or improve existing stroke frameworks to achieve high-quality, evidence-based recommendations and ensure that outcomes are measured to foster a milieu for continuous improvement (29).

\section{The need for grading recommendations}

While countries have their own specific treatment recommendations, grading of evidence with the use of standardized systems are lacking. It is essential for guidelines to incorporate these as it ensures transparency and some level of confidence as these recommendations are translated into clinical practice (31). Various country-specific guidelines make use of their own grading systems in assessing the weight and level of evidence of the recommended guidelines (29). It is also essential for grading systems to be customized accordingly for low-income countries. Epidemiologists suggest the adaptation of internationally recognized approaches with efforts to integrate local evidence and weigh in appropriate resources (32).

\section{Clinical trials that changed the guidelines}

In 1994, the AHA published the first clinical guideline on the management of acute ischemic stroke (33). While the efficacy of thrombolytic therapy was already being recognized then, it remained to be in the sidelines for safety concerns $(34,35,37)$. With the encouraging results of the NINDs trial and the subsequent approval of alteplase by the US-FDA for systemic reperfusion, the AHA guidelines was updated, and it was also within this period that the Canadian Stroke Guidelines was conceived (36). Other major clinical guidelines from different parts of the world were also published subsequently. 
15 Scoping Review of Existing Stroke Guidelines; Argument for a Value-Added Change

With the aim of further improving stroke care, further modifications of then existing guidelines have been made. With the promising results of the ECASS3 trial, the time period for thrombolysis has been extended from three to 4.5 hours (38-39). The results of the J-ACT trial in 2006 has also resulted in the approval for use of the $0.6 \mathrm{mg} / \mathrm{kg}$ dose of alteplase as mandated by the revised 2009 Japanese guidelines for stroke $(18,40)$

The results of five clinical trials on endovascular therapy from 2012 to 2014 have also revolutionized the landscape of stroke management in the year 2015. The MR CLEAN, ESCAPE, EXTEND-IA, SWIFT-PRIME and the REVASCAT trials showed statistically significant improvement in clinical and radiologic outcomes after endovascular therapy (EVT) for large vessel occlusion (41-45). Clinical guidelines were revised so that patients within six hours from onset of symptoms were deemed eligible for EVT $(12,14,26)$. A few years later, this time period was extended to $18-26$ hours based on perfusion imaging parameters, as demonstrated by the DAWN and the DEFFUSE 3 trials $(46,47)$. Various clinical trials are still in the pipeline and are expected to make significant changes in existing guidelines worldwide in the future.

\section{Initial assessment}

Guidelines included in the study are represented from all parts of the world including Asia, Australia, Europe, Africa and America (Table 2). Sections of clinical guidelines are subdivided into initial assessment, supportive treatment, reperfusion therapy, management of complications and rehabilitation. In most guidelines, pre-hospital and preventive strategies are 
16 Scoping Review of Existing Stroke Guidelines; Argument for a Value-Added Change

usually included, but these are not discussed in this study. It is noted that some degree of variability in grading exists with the appraisal of different clinical guidelines.

In terms of initial assessment, there is unanimity in the clinical strategies that all patients suspected to have stroke should have neuroimaging urgently. This received the strongest recommendation among most of the countries with only ones from USA and Qatar, putting significant weight on aiming less than 20 minutes for it to be accomplished. High-income countries who have established facilities for endovascular thrombectomy also put the priority on neurovascular imaging. On the other hand, only a number of countries emphasize the use of scales for stroke severity assessment.

The importance of neuroimaging cannot be overemphasized in the management of acute stroke. While seamless processes to ensure efficiency in initial brain scanning have already been established in high-income countries, limitations in resources and logistics are still problematic most especially in rural areas of low to middle-income countries $(48,49)$. For example, a tertiary centre in India identified that the lack of neuroimaging facilities posed as one of the most important barriers for thrombolysis, with even the out of pocket cost for CT scan contributing to this limitation (50). It is also practical for other countries such as Sri Lanka, Serbia(51), South Africa and Malaysia not to put too much weight on neurovascular imaging as inaccessibility to neuro-interventionists and comprehensive stroke centres, as well as the high cost of treatment for this sophisticated procedure $(51,52)$, is still one of the identified problems in most developing countries (53). On the other hand, among countries in which reputable standard operating procedures for neuroimaging are already existent, aiming to 
17 Scoping Review of Existing Stroke Guidelines; Argument for a Value-Added Change

shorter door to imaging times are being optimized, as trends to improved clinical outcomes have been observed (54).

There is also homogeneity among different countries in terms of what ancillary tests are to be performed during the hyperacute management of stroke. Serum blood glucose is being specified as an absolute test to be done prior to thrombolysis in some countries while in some, this is not explicitly identified. There is also unanimity among different countries that troponin, immune cell counts, and ECG should not be deterrents to timely thrombolysis. While obtaining baseline temperature is deemed significant in almost all clinical guidelines, less degree of weight is put in this parameter as opposed to blood glucose.

It has long been recognized that hypo and hyperglycaemia are known stroke masquerades (55). A study in 2015 among 80 consecutively recruited hypoglycemic patients revealed that $11 \%$ had stroke-like presentation with symptoms reversing within one hour of administration of intravenous dextrose (56). Furthermore, it is also essential that this parameter be recognized and corrected at an early stage as glycaemic aberrations in the peri-thrombolysis period may significantly impact on clinical outcomes (57). While deemed equally important, cardiac investigations should not preclude nor delay thrombolysis. It has been demonstrated in various studies that the presence of strain pattern, t-wave alterations, QT dispersion may be predictors of poor outcomes among stroke patients (58-60). Troponin is also essential to exclude the cooccurrence of AIS and acute myocardial infarction. A national registry including more than 800,000 patients with AIS identified that simultaneous occurrence of both only happens in $1.6 \%$ of the patients (61). While the incidence is significantly low, substantial increase in hospital mortality has been observed (61). 
18 Scoping Review of Existing Stroke Guidelines; Argument for a Value-Added Change

\section{General supportive care}

There is heterogeneity in terms of supportive care among acute stroke patients with most clinical guidelines stressing moderate to strong recommendations on airway protection, correction of fluid imbalances and treatment of sources of hyperthermia and hypoglycaemia. Consensus for blood pressure targets are not uniform, with Caucasian guidelines emphasizing a threshold of 180/105 prior to thrombolysis while some Asian guidelines follow a higher target $(19,22)$.

It is essential that acute stroke units be organized in a manner that caters to the efficient provision of above-mentioned parameters as this has been positively associated with good outcomes such as reduction of mortality, length and cost of hospitalization as well as institutionalization $(62,63)$. This is particularly problematic in low to middle income countries because of concerns for costs, facilities and hospital staffing(64) Contrary to this, a recent prospective observational study in a tertiary hospital in South Africa demonstrated that despite the resource limitations, adaptation of the acute stroke response network which integrates organization of an acute stroke unit yields favourable thrombolysis outcomes at par to those observed in developed countries $(65,66)$.

Evidence proves that blood pressure optimization during thrombolysis results in good functional outcomes (67). Prospective and retrospective studies as well as clinical trials reveal that blood pressure during thrombolysis ranging from 140-160 reduced the odds of poor outcomes (68-69). To date, no studies have identified the most optimal blood pressure to 
19 Scoping Review of Existing Stroke Guidelines; Argument for a Value-Added Change

achieve best outcomes post reperfusion therapy, however, clinical trial targets are set at 180/105, hence the parameters set in clinical guidelines (70).

\section{Thrombolysis and the management of medical and surgical complications}

There is also agreement between different guidelines that thrombolytic therapy at a dose of $0.9 \mathrm{mg} / \mathrm{kg}$ be instituted among eligible patients who arrive between three to 4.5 hours from the onset of symptoms. It is only the Japanese guideline which has approved of the use of the lower dose $(0.6 \mathrm{mg} / \mathrm{kg})$. Also, only a few guidelines explicitly emphasize recommendations on the management of bleeding and angioedema after treatment. Neurosurgical recommendations for the management of malignant infarcts and obstructive hydrocephalous are also clearly defined in medium and high-income countries

Majority of the clinical trials which looked at the safety and efficacy of the low-dose alteplase was employed among Asians, specifically Japanese(71,72). The favourable results of the JACT, ENCHANTED, THAWS trial support the Japanese recommendations $(70,71,72,73)$. Aside from practical reasons of the lower cost from the reduced dose of alteplase (which usually just consumes 1 vial per dose), physiologic advantages such as lower levels of 
20 Scoping Review of Existing Stroke Guidelines; Argument for a Value-Added Change

fibrinogen and Plasminogen Activator Inhibitor-1 (PAI-1) along with less marked genetic polymorphisms that induces a higher state of coagulation compared to Caucasians have also cited by Ueshima and colleagues (74). On the other hand, thrombolysis of patients with unclear onset of symptoms but with eligibility according the neuroimaging parameters of the WAKEUP trial have also made the Australian and the AHA stroke guidelines recommend in favour of the later (75).

It is also interesting to note that of the guidelines reviewed, only three had explicitly stated recommendations on the management of thrombolysis-related complications such as bleeding and angioedema. More so, of the Asian countries included, only Japan had clear statements with this regard(76). It is equally important to address these limitations especially in resourcelimited regions such as Asia and South America, where there is also a scarcity of stroke intensive care units $(77,78)$.

Encouraging results of various clinical trials for the management of malignant supra and infratentorial infarctions have been instrumental for the increase in confidence for guidelines to recommend these procedures especially for highly eligible patients. While this is of no question for countries with sufficient infrastructure and manpower, it has always been challenging for low- and middle-income countries. In sub-Saharan Africa, it has been previously identified that the ratio of neurosurgeon to population is as low 1: $64,000,000$ (79). Furthermore, a study in 2015 on the economic losses attributed to neurosurgical diseases revealed that stroke was a major contributor to the three trillion macroeconomic deficits particularly in low income countries (80). It is therefore critical that guidelines be crafted according to individually available resources to ensure optimal implementability. 
21 Scoping Review of Existing Stroke Guidelines; Argument for a Value-Added Change

\section{Post-stroke rehabilitation}

Stroke rehabilitation is another key component of stroke clinical guidelines. Majority put significant weight on early rehabilitation while moderate to weak strengths have been tagged for professional dysphagia assessment. The American, Australian and UK guidelines likewise put high premium on functional assessment while heterogeneity exists on integrating rehabilitation on comprehensive stroke care centre as well as the use of intermittent pneumatic compression for deep vein thrombosis. Majority of the guidelines have weak or no recommendations for depression screening and treatment, as well as regular skin assessment.

One of the aspects of stroke care that most clinicians fail to put attention into is post-acute rehabilitation. It is important for healthcare systems to adhere to posts-stroke rehabilitation guidelines as various studies have shown that compliance is positively correlated with good clinical outcomes (81-82). It has also been shown that low-cost rehabilitation (83) with focus on exercise-based and brain training interventions, in resource-deprived settings still translated to good clinical outcomes (84). Commensurate rehabilitation initiated within the first seven days of stroke has been shown to initiate complex neurobiological processes which is instrumental in early neurologic recovery as evidenced in various clinical trials $(85,86)$. Various clinical settings have also confirmed that post-stroke dysphagia results in aspiration pneumonia which further complicates hospital outcomes $(88,89,90)$. Additionally, evidencebased practices for the prevention of deep vein thrombosis such as the use of IPC, should likewise be integrated as it may likewise impact on survival (91). Likewise, there should be increased vigilance for post-stroke depression among clinicians as it may occur in more than one third of stroke cases (91). The need to integrate this in clinical guidelines could not be 
22 Scoping Review of Existing Stroke Guidelines; Argument for a Value-Added Change

over-emphasized especially in low-income to middle income countries due to its increasing prevalence $(92,93)$. Moreover, its impact on the disability-adjusted life-years lost is significantly greater in than in high income countries $(94,95)$

\section{Ignored aspects of stroke care}

The abundance of sophisticated techniques for stroke care has led clinicians to forget about the basic yet practical aspects of stroke management. It is noted that none of the stroke guidelines incorporate the use of basic immune biomarkers such as the neutrophil to lymphocyte ratio. In the advent of precision medicine nowadays, clinical practice is shifting towards accurate and specific disease characterization, as well as quantifying disease progression and response to therapy, for which biomarkers play critically important role (96). The neutrophil to lymphocyte ratio is a cheap, readily available and easy to interpret immune marker which may provide a diagnostic clue particularly for clinical outcomes post stroke (97-99).

While not mentioned in any of the clinical guidelines, the importance of ocular examination in stroke care should not be discounted. Fundus photography is an emerging tool which may assist in differentiating of stroke and TIA from other causes of neurologic deficits, particularly in the emergency setting (100). Retinal imaging, otherwise known as the 'window to the brain' may supplement neuroimaging particularly in providing insights for cerebrovascular neurodegenerative conditions (101). Lastly, it may also provide additional information for identifying stroke aetiology, especially that of complicated ones (102). 
23 Scoping Review of Existing Stroke Guidelines; Argument for a Value-Added Change

\section{Discussion}

Stroke and post stroke complications culminating in massive health and economic impacts globally(103). Stroke occurs in a compromised vascular system . The risk factors associated with stroke ( both non-modifiable risk factors such as genetic, age, gender and modifiable risk factors such as hypertension, diabetes, high cholesterol, sedentary lifestyle, reduced fruits and vegetable intake, obesity, atrial fibrillation, poor air quality, smoking are linked with the build-up of low-grade chronic inflammation that perturbs the homeostasis of the vascular bed prior to the index vascular event such as acute stroke .

The index vascular event leads to a cascade of events that involve bioenergetic failure, disrupted cellular homeostasis, excitotoxicity, acidosis, damaged blood brain barrier and cell death very much akin to COVID-19 and brain involvement(104,106).

Contrary to the traditional belief that brain and immune systems are physically separate systems the neural and immune systems are intimately linked through SNS, HPA axis and also through glymphatic systems where bidirectional communication does occur regularly $(107,108)$.

There were 80.2 million (74.1 to 86.3 ) prevalent strokes globally in 2016 (109). Post stroke cognitive impairment has been reported over 50\% (which is still a gross underestimation ) of stroke survivors with worsened disability and quality of life (110) . Frequency of anxiety after stroke very high at $24.2 \%(21.5 \%-26.9 \%)$ by rating scales (111) with likely increased risk of further stroke and downward spiral from the PNI point of view. Post stroke depression (PSD) is reported at 18\%-33\% (112) ( gross under estimation again, see the comprehensive review on pathobiology of PSD Pascoe \& Crewther (113) ). Post Stroke Fatigue (PSF) is 
24 Scoping Review of Existing Stroke Guidelines; Argument for a Value-Added Change

reported as one of the worst symptoms by $40 \%$ of the stroke survivors with prevalence of PSF vary from $25 \%-85 \%(114,115,117)$. Post Stroke Apathy(PSA) with a prevalence $34.6 \%$ and Central Post Stroke Pain (CPSP) with a prevalence vary from 8\%-55\% (116,117),can be added to long list of post stroke neurological complications with a similar psychoneuroimmunological pathobiology to the PCNS as we elaborated in a series of recent publications (104-106)

We suggest the desperate need of systems biology approach to all these complications and conder the complete picture with a view to optimise the best immune response after the index event of acute stroke and re-visit the current guidelines as a matter of high priority. Such an approach will help the world to address one of the most disabling brain disorders affecting well over 80 million people with excellent value for money with current management approach and also the potential for individualized therapeutic and management avanues.

\section{Conclusion}

Stroke management is a dynamic process which has evolved at a very fast pace over the past two decades. With the abundance of clinical trials in this field, it is possible that trends of management now may not be applicable in the future. Despite this, it is disappointing to see the lack of incorporation of easily accessible, low cost immune inflammatory prognostic markers such as NLR, or functional vision assessment at the bed side in any of the published stroke guidelines anywhere in the world. This is despite the fact that large number of publications and metanalyses supporting the role of immune inflammatory markers such as 
25 Scoping Review of Existing Stroke Guidelines; Argument for a Value-Added Change

NLR in acute stroke as well as in the context of post stroke trajectory. It is therefore imperative for country-specific standard operating procedures to be updated constantly to fit to emerging needs with a systems biology-based approach. Implementability of clinical guidelines is anchored on evidence-based and well-appraised clinical guidelines which are customized according to available resources and to the beliefs of its end-users. 
26 Scoping Review of Existing Stroke Guidelines; Argument for a Value-Added Change

Wijeratne et al, 2021 
28 Scoping Review of Existing Stroke Guidelines; Argument for a Value-Added Change

Wijeratne et al, 2021

Preprints (www.preprints.org) | NOT PEER-REVIEWED | Posted: 16 February 2021

preprints202102.0328.v1 (1) 


\title{
30 Scoping Review of Existing Stroke Guidelines; Argument for a Value-Added Change
}

\begin{tabular}{|c|c|c|c|c|c|c|c|c|c|c|c|c|c|c|c|c|}
\hline & \multicolumn{10}{|c|}{ Initial Assessment } & \multicolumn{6}{|c|}{ General Supportive Care } \\
\hline & $\begin{array}{l}\text { The use of } \\
\text { a severity } \\
\text { scale on } \\
\text { initial } \\
\text { assessment }\end{array}$ & $\begin{array}{c} \\
\\
\text { All } \\
\text { suspected } \\
\text { stroke } \\
\text { patients } \\
\text { should } \\
\text { have } \\
\text { initial } \\
\text { brain } \\
\text { imaging }\end{array}$ & $\begin{array}{c}\text { Brain } \\
\text { imaging } \\
\text { should } \\
\text { be done } \\
\text { within } \\
20 \\
\text { minutes } \\
\text { in at at } \\
\text { least } \\
50 \% \text { of } \\
\text { patients } \\
\text { eligible } \\
\text { for } \\
\text { treatment }\end{array}$ & $\begin{array}{c} \\
\\
\text { Non- } \\
\text { invasive } \\
\text { vascular } \\
\text { imaging } \\
\text { should not } \\
\text { delay } \\
\text { thrombolysis }\end{array}$ & $\begin{array}{c}\text { Objective } \\
\text { visual } \\
\text { assessment }\end{array}$ & $\begin{array}{c}\text { Baseline } \\
\text { temperature }\end{array}$ & $\begin{array}{l}\text { Only the } \\
\text { assessment } \\
\text { of blood } \\
\text { glucose } \\
\text { must } \\
\text { precede } \\
\text { the } \\
\text { initiation } \\
\text { of } \\
\text { IV } \\
\text { alteplase } \\
\text { in all } \\
\text { patients. }\end{array}$ & $\begin{array}{c}\text { Baseline } \\
\text { ECG } \\
\text { assessment } \\
\text { but should } \\
\text { not delay } \\
\text { initiation } \\
\text { of IV } \\
\text { alteplase. }\end{array}$ & $\begin{array}{c}\text { Baseline } \\
\text { troponin } \\
\text { assessment } \\
\text { but should } \\
\text { not delay } \\
\text { initiation } \\
\text { of IV } \\
\text { alteplase }\end{array}$ & $\begin{array}{c}\text { Baseline } \\
\text { Immune } \\
\text { Cell } \\
\text { Counts } \\
\text { such as } \\
\text { Full Blood } \\
\text { Count to } \\
\text { assess } \\
\text { neutrophil } \\
\text { to } \\
\text { lymphocyte } \\
\text { ratio }\end{array}$ & $\begin{array}{l}\text { Airway and } \\
\text { ventilation } \\
\text { support for } \\
\text { patients with } \\
\text { decreased } \\
\text { consciousness } \\
\text { and with } \\
\text { bulbar } \\
\text { dysfunction }\end{array}$ & $\begin{array}{c}\text { Supplemental } \\
\text { oxygen if } \\
\text { oxygen } \\
\text { saturation } \\
>94 \%\end{array}$ & $\begin{array}{c}\text { Early } \\
\text { treatment } \\
\text { of BP if } \\
\text { with } \\
\text { compelling } \\
\text { indications }\end{array}$ & $\begin{array}{l}\text { Correction } \\
\text { of } \\
\text { hypotension } \\
\text { and } \\
\text { hypovolemia }\end{array}$ & $\begin{array}{c}\text { Treatment of } \\
\text { sources of } \\
\text { hyperthermia }\end{array}$ & $\begin{array}{l}\text { Correction of } \\
\text { hypoglycaemia }\end{array}$ \\
\hline Australia & Not set & Strong & NES & Strong & $\mathrm{N}$ & Strong & NES & Weak & $\mathrm{N}$ & $\mathrm{N}$ & NES & NES & NES & $\mathrm{N}$ & Weak & NES \\
\hline Brazil & $\mathrm{N}$ & I-A & $\mathrm{N}$ & I-A & $\mathrm{N}$ & $\mathrm{N}$ & NES & NES & $\mathrm{N}$ & $\mathrm{N}$ & 5-D & 2B-B & 5 -D & 5-D & 5-D & 5.D \\
\hline Canadian & $\mathrm{C}$ & A & NES & $\mathrm{A}$ & $\mathrm{N}$ & $\mathrm{B}$ & A & $\mathrm{C}$ & $\mathrm{C}$ & $\mathrm{C}$ & B & NES & $\mathrm{C}$ & $\mathrm{C}$ & B & B \\
\hline Chinese & NES & IIB-b & NES & 2B-B & $\mathrm{N}$ & $\mathrm{N}$ & $1-\mathrm{A}$ & NES & $\mathrm{N}$ & NES & $\mathrm{N}$ & $\mathrm{N}$ & NES & $\mathrm{N}$ & $\mathrm{N}$ & $1-\mathrm{A}$ \\
\hline ESO & NES & I-A & NES & I-A & $\mathrm{N}$ & $\mathrm{N}$ & NES & NES & $\mathrm{N}$ & $\mathrm{N}$ & NES & IV-GCP & I-A & IV-GCP & IV-GCP & $\mathrm{C}$ \\
\hline Italy & NES & NES & $\mathrm{N}$ & NES & $\mathrm{N}$ & $\mathrm{N}$ & NES & $\mathrm{N}$ & $\mathrm{N}$ & $\mathrm{N}$ & $\mathrm{N}$ & $\mathrm{N}$ & $\mathrm{N}$ & $\mathrm{N}$ & $\mathrm{N}$ & NES \\
\hline Japan & Low-A & High-A & NES & High-A & $\mathrm{N}$ & $\mathrm{N}$ & NES & $\mathrm{N}$ & $\mathrm{N}$ & $\mathrm{N}$ & $\mathrm{N}$ & $\mathrm{N}$ & NES & $\mathrm{N}$ & $\mathrm{N}$ & NES \\
\hline
\end{tabular}

\section{Initial Assessment}

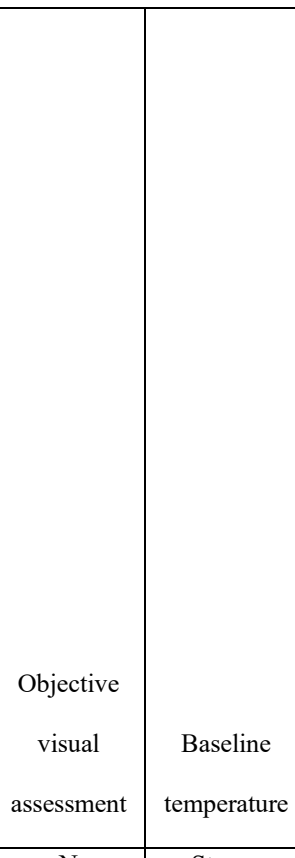

\author{
(
}




\begin{tabular}{|c|c|c|c|c|c|c|c|c|c|c|c|c|c|c|c|c|}
\hline \multicolumn{17}{|c|}{31 Scoping Review of Existing Stroke Guidelines; Argument for a Value-Added Change } \\
\hline Malaysian & NES & NES & $\mathrm{N}$ & $\mathrm{N}$ & $\mathrm{N}$ & II-1 & NES & $\mathrm{N}$ & $\mathrm{N}$ & $\mathrm{N}$ & IIII-C & NES & NES & NES & IIII-C & III-C \\
\hline Qatar & $\mathrm{N}$ & R-CDG & R-CDG & NES & $\mathrm{N}$ & NES & NES & NES & NES & NES & NES & NES & $\mathrm{N}$ & $\mathrm{N}$ & $\mathrm{N}$ & NES \\
\hline Scotland & $\mathrm{C}$ & A & NES & NES & $\mathrm{N}$ & NES & NES & $\mathrm{N}$ & $\mathrm{N}$ & $\mathrm{N}$ & $\mathrm{D}$ & NES & NES & NES & C & $\mathrm{C}$ \\
\hline Singapore & $\mathrm{N}$ & 2C-GPP & $\mathrm{N}$ & NES & $\mathrm{N}$ & NES & $\begin{array}{l}\text { GPP } \\
\end{array}$ & $\mathrm{N}$ & $\mathrm{N}$ & $\mathrm{N}$ & $\mathrm{N}$ & $\mathrm{N}$ & GPP & $\mathrm{N}$ & 4-D & GPP \\
\hline South Africa & NES & $\begin{array}{l}\text { I-A } \\
\end{array}$ & NES & NES & $\mathrm{N}$ & $\begin{array}{l}\text { IV-GCP } \\
\end{array}$ & NES & I-A & I-A & $\mathrm{N}$ & NES & IV-GCP & IV-GCP & $\begin{array}{l}\text { IV-GCP } \\
\end{array}$ & $\begin{array}{l}\text { IV-GCP } \\
\end{array}$ & $\begin{array}{l}\text { IV-GCP } \\
\end{array}$ \\
\hline Sri Lanka & $\mathrm{N}$ & B & $\mathrm{N}$ & $\mathrm{N}$ & $\mathrm{N}$ & NES & NES & NES & $\mathrm{N}$ & $\mathrm{N}$ & $\mathrm{N}$ & NES & NES & NES & NES & NES \\
\hline UK & NES & A & NES & $\mathrm{D}$ & $\mathrm{N}$ & B & A & NES & $\mathrm{N}$ & $\mathrm{N}$ & D & C & I & $\mathrm{D}$ & NES & $\mathrm{H}$ \\
\hline USA & I-B & I-B & I-B & I-A & $\mathrm{N}$ & I-C & I-B & I-B & I-B & $\mathrm{N}$ & I-C & I-C & Not graded & IC-EO & I-C & I-C \\
\hline
\end{tabular}

\begin{tabular}{|l|c|}
\hline & Management of Complications \\
\hline
\end{tabular}

\section{Scoping Review of Existing Stroke Guidelines; Argument for a Value-Added Change \\ (1) Scoping Review of Existing Stroke Guidelines; Argument for a Value-Added Change}

$\sqrt{2}$

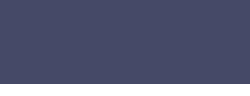

.

(2)

\begin{tabular}{l|l} 
Country & Thrombolysis \\
\hline
\end{tabular}




\begin{tabular}{|c|c|c|c|c|c|c|c|c|c|c|c|c|c|c|c|c|c|c|c|c|}
\hline & $\begin{array}{c}\text { IV } \\
\text { altepla } \\
\text { se } \\
\text { within } \\
3 \text { hours } \\
\text { of } \\
\text { ischem } \\
\text { ic } \\
\text { stroke } \\
\text { sympto } \\
\text { m } \\
\text { onset } \\
\text { or } \\
\text { patient } \\
\text { last } \\
\text { known } \\
\text { well or } \\
\text { at } \\
\text { baselin } \\
\text { e state. }\end{array}$ & $\begin{array}{l}\text { IV } \\
\text { alteplas } \\
\mathrm{e} \\
\text { within } \\
3 \text { and } \\
4.5 \\
\text { hours } \\
\text { of } \\
\text { ischem } \\
\text { ic } \\
\text { stroke } \\
\text { sympto } \\
\mathrm{m} \\
\text { onset } \\
\text { or } \\
\text { patient } \\
\text { last } \\
\text { known } \\
\text { well or } \\
\text { at } \\
\text { baselin } \\
\text { e state. }\end{array}$ & $\begin{array}{c}\text { Discussio } \\
\text { nof risk } \\
\text { and } \\
\text { benefitis of } \\
\text { thromboly } \\
\text { sis during } \\
\text { decision } \\
\text { making }\end{array}$ & $\begin{array}{c}\text { Preparatio } \\
\text { n for } \\
\text { complicati } \\
\text { ons such as } \\
\text { bleeding } \\
\text { and } \\
\text { angioedem } \\
\text { a }\end{array}$ & $\begin{array}{c}\text { BP should } \\
\text { be } \\
\text { maintaine } \\
\text { d } \\
<180 / 105 \\
\text { mmHg } \\
\text { before } \\
\text { thromboly } \\
\text { sis }\end{array}$ & $\begin{array}{l}\text { The use if } \\
\text { comprehens } \\
\text { ive stroke } \\
\text { care with } \\
\text { rehabilitatio } \\
\text { n }\end{array}$ & $\begin{array}{l}\text { The } \\
\text { use of } \\
\text { IPC in } \\
\text { additi } \\
\text { on to } \\
\text { routin } \\
\text { e care } \\
\text { for } \\
\text { DVT }\end{array}$ & $\begin{array}{c}\text { Use of } \\
\text { inventori } \\
\text { es for } \\
\text { depressi } \\
\text { on } \\
\text { screenin } \\
\text { g }\end{array}$ & $\begin{array}{c}\text { Treatme } \\
\text { nt of } \\
\text { post- } \\
\text { stroke } \\
\text { depressi } \\
\text { on with } \\
\text { ant- } \\
\text { depressa } \\
\text { nts }\end{array}$ & $\begin{array}{l}\text { Use of } \\
\text { objectiv } \\
\text { e scales } \\
\text { for skin } \\
\text { assessm } \\
\text { ent }\end{array}$ & $\begin{array}{c}\text { Dyspha } \\
\text { gia } \\
\text { screenin } \\
\text { g by a } \\
\text { trained } \\
\text { healthca } \\
\text { re } \\
\text { provider }\end{array}$ & $\begin{array}{c}\text { Early } \\
\text { rehabilitatit } \\
\text { on by an } \\
\text { organized } \\
\text { multi- } \\
\text { disciplinar } \\
\text { y team }\end{array}$ & $\begin{array}{c}\text { Rehabilitati } \\
\text { on intensity } \\
\text { commensur } \\
\text { ate with } \\
\text { tolerance }\end{array}$ & $\begin{array}{c}\text { Formal } \\
\text { assessmen } \\
\text { tof } \\
\text { functional } \\
\text { ity and } \\
\text { deficits in } \\
\text { the acute } \\
\text { stage and } \\
\text { before } \\
\text { discharge }\end{array}$ & $\begin{array}{c}\text { A } \\
\text { function } \\
\text { al } \\
\text { assessm } \\
\text { ent by a } \\
\text { clinician } \\
\text { with } \\
\text { expertise } \\
\text { in } \\
\text { for } \\
\text { residual } \\
\text { function } \\
\text { al } \\
\text { defícits. }\end{array}$ & $\begin{array}{c}\text { Ventriculosto } \\
\text { my for } \\
\text { obstructive } \\
\text { hydrocephalu } \\
\mathrm{s} \text { after a } \\
\text { cerebellar } \\
\text { infarct. }\end{array}$ & $\begin{array}{c}\text { Decompress } \\
\text { ive } \\
\text { suboccipital } \\
\text { for } \\
\text { cerebellar } \\
\text { infarction } \\
\text { causing } \\
\text { neurological } \\
\text { deterioratio } \\
\mathrm{n}\end{array}$ & $\begin{array}{c}\text { Decompressiv } \\
\mathrm{e} \\
\text { Hemicraniect } \\
\text { omy for } \\
\text { supratentorial } \\
\text { infarctions }\end{array}$ & $\begin{array}{c}\text { Transfer } \\
\text { of patients } \\
\text { with } \\
\text { malignant } \\
\text { brain } \\
\text { oedema to } \\
\text { an } \\
\text { institution } \\
\text { with } \\
\text { neurosurgi } \\
\text { cal } \\
\text { expertise } \\
\text { should be } \\
\text { considered }\end{array}$ & $\begin{array}{c}\text { Treatme } \\
\text { nt of } \\
\text { recurren } \\
\mathrm{t} \\
\text { seizures } \\
\text { like any } \\
\text { other } \\
\text { acute } \\
\text { neurolo } \\
\text { gic } \\
\text { conditio } \\
\text { n. }\end{array}$ \\
\hline Australia & NES & Strong & NES & $\mathrm{N}$ & $\mathrm{N}$ & Strong & Weak & Not set & Weak & NES & Weak & Strong & Strong & Strong & Strong & NES & $\begin{array}{c}\text { Practice } \\
\text { Statement }\end{array}$ & Weak & NES & NES \\
\hline Brazil & $\mathrm{N}$ & $\mathrm{N}$ & NES & NES & 1-A & NES & $\mathrm{N}$ & $\mathrm{N}$ & $\mathrm{N}$ & $\mathrm{N}$ & $\mathrm{N}$ & $\mathrm{N}$ & $\mathrm{N}$ & $\mathrm{N}$ & $\mathrm{N}$ & $\mathrm{N}$ & $\mathrm{N}$ & $\mathrm{N}$ & $\mathrm{N}$ & $\mathrm{N}$ \\
\hline Canadian & $\mathrm{A}$ & $\mathrm{A}$ & NES & C & $\begin{array}{l}\mathrm{C} \\
\end{array}$ & NES & $\mathrm{A}$ & B & C & NES & C & $\mathrm{A}$ & $\mathrm{A}$ & B & C & $\mathrm{A}$ & C & C & $\mathrm{C}$ & $\mathrm{C}$ \\
\hline Chinese & 1-A & 1-B & NES & NES & 1-B & & II-A & I-B & I-B & NES & I-A & $\mathrm{I}-\mathrm{C}$ & I-A & lia-C & lia-C & $\mathrm{N}$ & $\mathrm{N}$ & $\mathrm{N}$ & $\mathrm{N}$ & $\mathrm{N}$ \\
\hline ESO & I-A & I-B & NES & NES & $\mathrm{IV}, \mathbf{G C P}$ & NES & $\mathrm{N}$ & NES & III-B & NES & IIII-GCP & I-A & III-B & NES & NES & IIILC & IIII-C & I-A & NES & \\
\hline
\end{tabular}

\section{Scoping Review of Existing Stroke Guidelines; Argument for a Value-Added Change}

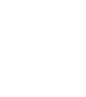

Wijeratne et al, 2021
} 
33 Scoping Review of Existing Stroke Guidelines; Argument for a Value-Added Change

\begin{tabular}{|c|c|c|c|c|c|c|c|c|c|c|c|c|c|c|c|c|c|c|c|c|}
\hline $\begin{array}{l}\text { Italy } \\
\end{array}$ & $\mathrm{A}$ & A & NES & NES & NES & $\mathrm{N}$ & $\mathrm{N}$ & $\mathrm{N}$ & NES & NES & C & C & C & NES & NES & $\mathrm{N}$ & $\mathrm{N}$ & $\mathrm{N}$ & $\mathrm{N}$ & NES \\
\hline Japan & NES & $\begin{array}{c}\text { High-A } \\
\text { for } \\
0.6 \mathrm{mg} / \\
\mathrm{kg}\end{array}$ & $\begin{array}{l}\text { Cl- } \\
\text { Midde }\end{array}$ & Low-B & Low-B & NES & $\mathrm{N}$ & $\mathrm{N}$ & $\mathrm{N}$ & $\mathrm{N}$ & $\mathrm{N}$ & $\mathrm{N}$ & $\mathrm{N}$ & $\mathrm{N}$ & $\mathrm{N}$ & NES & NES & NES & NES & $\mathrm{N}$ \\
\hline Malaysian & $\mathrm{N}$ & $\mathrm{I}-\mathrm{A}$ & $\mathrm{N}$ & $\mathrm{N}$ & $\mathrm{N}$ & $\mathrm{N}$ & $\mathrm{N}$ & $\mathrm{N}$ & $\mathrm{N}$ & $\mathrm{N}$ & $\mathrm{N}$ & $\mathrm{N}$ & $\mathrm{N}$ & $\mathrm{N}$ & $\mathrm{N}$ & III-C & III-C & II3-C & NES & $\mathrm{N}$ \\
\hline Qatar & $\mathrm{N}$ & 2-RGA & NES & $\mathrm{N}$ & NES & NES & NES & $\mathrm{N}$ & $\mathrm{N}$ & $\mathrm{N}$ & NES & R-CDG & NES & $\mathrm{N}$ & $\mathrm{N}$ & $\mathrm{N}$ & $\mathrm{N}$ & $\mathrm{N}$ & $\mathrm{N}$ & $\mathrm{N}$ \\
\hline Scotland & NES & $\mathrm{A}$ & NES & NES & $\mathrm{N}$ & $\mathrm{A}$ & $\mathrm{N}$ & $\mathrm{NES}$ & B & $\mathrm{N}$ & NES & $\mathrm{A}$ & $\mathrm{D}$ & $\mathrm{N}$ & $\mathrm{N}$ & $\mathrm{N}$ & $\mathrm{N}$ & $\mathrm{N}$ & $\mathrm{N}$ & $\mathrm{N}$ \\
\hline Singapore & $\mathrm{I}-\mathrm{A}$ & $\mathrm{I}-\mathrm{A}$ & NES & NES & $\mathrm{N}$ & $\mathrm{N}$ & $\mathrm{N}$ & $\mathrm{N}$ & $\mathrm{N}$ & $\mathrm{N}$ & $\mathrm{I}-\mathrm{A}$ & $\mathrm{I}-\mathrm{A}$ & NES & $\mathrm{N}$ & NES & 4-D & 4-D & $\mathrm{N}$ & $\mathrm{N}$ & $\mathrm{N}$ \\
\hline South Africa & $\mathrm{N}$ & $\mathrm{I}-\mathrm{A}$ & NES & NES & NES & NES & $\mathrm{N}$ & $\mathrm{N}$ & NES & $\mathrm{N}$ & III-GCP & III-C & NES & NES & NES & III-C & NES & I-A & NES & NES \\
\hline Sri Lanka & $\mathrm{N}$ & $\mathrm{N}$ & $\mathrm{N}$ & $\mathrm{N}$ & NES & $\mathrm{A}$ & $\mathrm{N}$ & $\mathrm{N}$ & $\mathrm{D}$ & NES & NES & NES & NES & $\mathrm{N}$ & $\mathrm{N}$ & $\mathrm{N}$ & $\mathrm{N}$ & $\mathrm{N}$ & $\mathrm{N}$ & $\mathrm{N}$ \\
\hline UK & $\mathrm{A}$ & B & NES & NES & $\mathrm{D}$ & $\mathrm{C}$ & $\mathrm{A}$ & NES & NES & $\mathrm{A}$ & $\mathrm{A}$ & $\mathrm{A}$ & $\mathrm{A}$ & $\mathrm{A}$ & $\mathrm{A}$ & $\mathrm{F}$ & $\mathrm{F}$ & $\mathrm{K}$ & $\mathrm{F}$ & NES \\
\hline USA & I-A & $\mathrm{I}-\mathrm{B}$ & $\mathrm{I}-\mathrm{C}$ & I-B & $\mathrm{I}-\mathrm{B}$ & I-A & I-B & $\mathrm{I}-\mathrm{B}$ & $\mathrm{I}-\mathrm{B}$ & I-C & IIla-C & I-A & I-B & $\mathrm{I}-\mathrm{B}$ & I-C & I-C & I-B & IIa-A & I-C & I-C \\
\hline
\end{tabular}

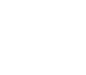

Proi:10.20944/preprints202102.0328.v1

\author{
(a)
}

(1)

Table 2. Summary of Recommendations in Various Stroke Guidelines (continued)

\begin{abstract}
(r) Argument for a Value-Added Change
\end{abstract}
$+2$

Table 2. Summary of Recommendations (1)

(1)

(1)

$\sqrt{2}$

(2)

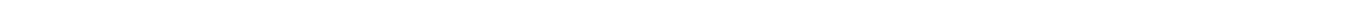


34 Scoping Review of Existing Stroke Guidelines; Argument for a Value-Added Change

\section{References:}

1. Reinmuth OM. Editorial: Prologue to guidelines for stroke care. Stroke. 1974 JanFeb;5(1):109-11. doi: 10.1161/01.str.5.1.109. PMID: 4590282.

2. Counsell C, Warlow C, Sandercock P, Fraser H, van Gijn J. The Cochrane Collaboration Stroke Review Group. Meeting the need for systematic reviews in stroke care. Stroke. 1995 Mar;26(3):498-502. PMID: 7886733.

3. Jakovljevic, M., Matter-Walstra, K., Sugahara, T., Sharma, T., Reshetnikov, V., Merrick, J., ... \& Rovira, J. (2020). Cost-effectiveness and resource allocation (CERA) 18 years of evolution: maturity of adulthood and promise beyond tomorrow. https://resource-allocation.biomedcentral.com/articles/10.1186/s12962-020-00210-2

4. Jakovljevic, M., Jakab, M., Gerdtham, U., McDaid, D., Ogura, S., Varavikova, E., ... \& Getzen, T. E. (2019). Comparative financing analysis and political economy of noncommunicable diseases. Journal of medical economics, 22(8), 722-727. https://www.tandfonline.com/doi/full/10.1080/13696998.2019.1600523

5. Mayer J, Kipps C, Cock HR. Implementing clinical guidelines. Pract Neurol. 2019 Dec;19(6):529-535. doi: 10.1136/practneurol-2017-001814. Epub 2019 Jun 12. PMID: 31189692.

6. Muche-Borowski C, Nothacker M, Kopp I. Leitlinienimplementierung : Wie schließen wir die Lücke zwischen Evidenz und Anwender? [Implementation of clinical practice guidelines: how can we close the evidence-practice gap?]. Bundesgesundheitsblatt Gesundheitsforschung Gesundheitsschutz. 2015 Jan;58(1):32-7. German. doi: 10.1007/s00103-014-2078-1. PMID: 25412582. 
35 Scoping Review of Existing Stroke Guidelines; Argument for a Value-Added Change

7. Guyatt G, Oxman AD, Akl EA, Kunz R, Vist G, Brozek J, Norris S, Falck-Ytter Y, Glasziou P, DeBeer H, Jaeschke R, Rind D, Meerpohl J, Dahm P, Schünemann HJ. GRADE guidelines: 1. Introduction-GRADE evidence profiles and summary of findings tables. J Clin Epidemiol. 2011 Apr;64(4):383-94. doi: 10.1016/j.jclinepi.2010.04.026. Epub 2010 Dec 31. PMID: 21195583.

8. Cabana MD, Rand CS, Powe NR, Wu AW, Wilson MH, Abboud PA, Rubin HR. Why don't physicians follow clinical practice guidelines? A framework for improvement. JAMA. 1999 Oct 20;282(15):1458-65. doi: 10.1001/jama.282.15.1458. PMID: 10535437.

9. Adams HP Jr, Brott TG, Furlan AJ, Gomez CR, Grotta J, Helgason CM, Kwiatkowski T, Lyden PD, Marler JR, Torner J, Feinberg W, Mayberg M, Thies W. Guidelines for thrombolytic therapy for acute stroke: a supplement to the guidelines for the management of patients with acute ischemic stroke. A statement for healthcare professionals from a Special Writing Group of the Stroke Council, American Heart Association. Circulation. 1996 Sep 1;94(5):1167-74. doi: 10.1161/01.cir.94.5.1167. PMID: 8790069.

10. Norris JW, Buchan A, Cote R, Hachinski V, Phillips SJ, Shuaib A, Silver F, Simard D, Teal P. Canadian guidelines for intravenous thrombolytic treatment in acute stroke. A consensus statement of the Canadian Stroke Consortium. Can J Neurol Sci. 1998 Aug;25(3):257-9. doi: 10.1017/s0317167100034120. PMID: 9706731

11. Freixa A, Moreira T, Bill O, Anani N. Implementability of stroke guidelines: a pragmatic comparison between US and European recommendations using eGLIA. Stud Health Technol Inform. 2015;210:256-60. PMID: 25991145. 
36 Scoping Review of Existing Stroke Guidelines; Argument for a Value-Added Change

12. Clinical guidelines - Stroke Foundation - Australia. Strokefoundation.org.au. (2020). Retrieved 12 October 2020, from https://strokefoundation.org.au/What-wedo/For\%20health\%20professionals\%20and\%20researchers/Clinical-guidelines.

13. Oliveira-Filho J, Martins SC, Pontes-Neto OM, Longo A, Evaristo EF, Carvalho JJ, Fernandes JG, Zétola VF, Gagliardi RJ, Vedolin L, Freitas GR; Executive Committee from Brazilian Stroke Society and the Scientific Department in Cerebrovascular Diseases. Guidelines for acute ischemic stroke treatment: part I. Arq Neuropsiquiatr. 2012 Aug;70(8):621-9. doi: 10.1590/s0004-282x2012000800012. PMID: 22899035.

14. Boulanger JM, Lindsay MP, Gubitz G, Smith EE, Stotts G, Foley N, Bhogal S, Boyle K, Braun L, Goddard T, Heran M, Kanya-Forster N, Lang E, Lavoie P, McClelland M, O'Kelly C, Pageau P, Pettersen J, Purvis H, Shamy M, Tampieri D, vanAdel B, Verbeek R, Blacquiere D, Casaubon L, Ferguson D, Hegedus Y, Jacquin GJ, Kelly M, Kamal N, Linkewich B, Lum C, Mann B, Milot G, Newcommon N, Poirier P, Simpkin W, Snieder E, Trivedi A, Whelan R, Eustace M, Smitko E, Butcher K. Canadian Stroke Best Practice Recommendations for Acute Stroke Management: Prehospital, Emergency Department, and Acute Inpatient Stroke Care, 6th Edition, Update 2018. Int J Stroke. 2018 Dec;13(9):949-984. doi: 10.1177/1747493018786616. Epub 2018 Jul 18. PMID: 30021503.

15. Dong Q, Dong Y, Liu L, Xu A, Zhang Y, Zheng H, Wang Y. The Chinese Stroke Association scientific statement: intravenous thrombolysis in acute ischaemic stroke. Stroke Vasc Neurol. 2017 Jun 2;2(3):147-159. doi: 10.1136/svn-2017-000074. PMID: 28989804; PMCID: PMC5628383.

16. Ahmed N, Audebert H, Turc G, Cordonnier C, Christensen H, Sacco S, Sandset EC, Ntaios G, Charidimou A, Toni D, Pristipino C, Köhrmann M, Kuramatsu JB, Thomalla 
37 Scoping Review of Existing Stroke Guidelines; Argument for a Value-Added Change

G, Mikulik R, Ford GA, Martí-Fàbregas J, Fischer U, Thoren M, Lundström E, Rinkel GJ, van der Worp HB, Matusevicius M, Tsivgoulis G, Milionis H, Rubiera M, Hart R, Moreira T, Lantz M, Sjöstrand C, Andersen G, Schellinger P, Kostulas K, Sunnerhagen KS, Keselman B, Korompoki E, Purrucker J, Khatri P, Whiteley W, Berge E, Mazya M, Dippel DW, Mustanoja S, Rasmussen M, Söderqvist ÅK, Escudero-Martínez I, Steiner T. Consensus statements and recommendations from the ESO-Karolinska Stroke Update Conference, Stockholm 11-13 November 2018. Eur Stroke J. 2019 Dec;4(4):307-317. doi: 10.1177/2396987319863606. Epub 2019 Sep 2. PMID: 31903429; PMCID: PMC6921948.

17. Inzitari D. The Italian Guidelines for stroke prevention. The Stroke Prevention and Educational Awareness Diffusion (SPREAD) Collaboration. Neurol Sci. 2000 Feb;21(1):5-12. doi: 10.1007/s100720070112. PMID: 10938196.

18. Shinohara Y. [Japanese Guidelines for the Management of Stroke 2009 : important revised points necessary for the neurologist]. Rinsho Shinkeigaku. 2010 Nov;50(11):80811. Japanese. doi: 10.5692/clinicalneurol.50.808. PMID: 21921447.

19. (2020). $\quad$ Retrieved $12 \quad$ October $\quad 2020, \quad$ from https://www.neuro.org.my/MSN_GUIDELINE/MSN_GUIDELINE_061112\%20CPG\% 20Management\%20of\%20Stroke\%20(ISBN\%20Code)\%202.pdf.

20. (2020). $\quad$ Retrieved $12 \quad$ October $\quad 2020, \quad$ from https://www.researchgate.net/publication/319376697_Clinical_Guidelines_for_the_Stat e_of_Qatar_The_diagnosis_and_management_of_stroke_and_transient_ischemic_attack 21. Scottish guidelines

22. Venketasubramanian N, Pwee KH, Chen CP; Singapore Ministry of Health Clinical Practice Guidelines Workgroup on Stroke and Transient Ischaemic Attacks. Singapore 
38 Scoping Review of Existing Stroke Guidelines; Argument for a Value-Added Change

ministry of health clinical practice guidelines on stroke and transient ischemic attacks. Int J Stroke. 2011 Jun;6(3):251-8. doi: 10.1111/j.1747-4949.2011.00602.x. PMID: 21557813.

23. Bryer A, Connor M, Haug P, Cheyip B, Staub H, Tipping B, Duim W, Pinkney-Atkinson V. South African guideline for management of ischaemic stroke and transient ischaemic attack 2010: a guideline from the South African Stroke Society (SASS) and the SASS Writing Committee. S Afr Med J. 2010 Nov 10;100(11 Pt 2):747-78. doi: 10.7196/samj.4422. PMID: 21081029.

24. Global-uploads.webflow.com. (2020). Retrieved 12 October 2020, from https://globaluploads.webflow.com/5e19f85d3feecdf9ff105b40/5e5f486f7b704fbc25d66298_CCPstroke-guidelines-1798.pdf.

25. Rudd AG, Bowen A, Young GR, James MA. The latest national clinical guideline for stroke. Clin Med (Lond). 2017;17(2):154-155. doi:10.7861/clinmedicine.17-2-154

26. Powers WJ, Rabinstein AA, Ackerson T, Adeoye OM, Bambakidis NC, Becker K, Biller J, Brown M, Demaerschalk BM, Hoh B, Jauch EC, Kidwell CS, Leslie-Mazwi TM, Ovbiagele B, Scott PA, Sheth KN, Southerland AM, Summers DV, Tirschwell DL. Guidelines for the Early Management of Patients With Acute Ischemic Stroke: 2019 Update to the 2018 Guidelines for the Early Management of Acute Ischemic Stroke: A Guideline for Healthcare Professionals From the American Heart Association/American Stroke Association. $\quad$ Stroke. 2019 Dec;50(12):e344-e418. doi: 10.1161/STR.0000000000000211. Epub 2019 Oct 30. Erratum in: Stroke. 2019 Dec;50(12):e440-e441. PMID: 31662037. 
39 Scoping Review of Existing Stroke Guidelines; Argument for a Value-Added Change

27. Mahawish K, Barber PA, McRae A, Slark J, Ranta AA. Why the new 'living' Australian Stroke Guidelines matter to New Zealand. N Z Med J. 2018 Dec 14;131(1487):12-14. PMID: 30543606.

28. Al-Jehani H, John S, Hussain SI, Al Hashmi A, Alhamid MA, Amr D, Ozdemir AO, Shuaib A, Alhazzani A, Ghorbani M, Mansour O, Saqqur M. MENA-SINO Consensus Statement on Implementing Care Pathways for Acute Neurovascular Emergencies During the COVID-19 Pandemic. Front Neurol. 2020 Aug 25;11:928. doi: 10.3389/fneur.2020.00928. PMID: 32982938; PMCID: PMC7477381.

29. Bayona H, Owolabi M, Feng W, et al. A systematic comparison of key features of ischemic stroke prevention guidelines in low- and middle-income vs. high-income countries. J Neurol Sci. 2017;375:360-366. doi:10.1016/j.jns.2017.02.040

30. Lindsay P, Furie KL, Davis SM, Donnan GA, Norrving B. World Stroke Organization global stroke services guidelines and action plan. Int J Stroke. 2014 Oct;9 Suppl A100:4-13. doi: 10.1111/ijs.12371. Epub 2014 Sep 23. PMID: 25250836.

31. Guyatt GH, Oxman AD, Vist GE, et al. GRADE: an emerging consensus on rating quality of evidence and strength of recommendations. BMJ. 2008;336(7650):924-926. doi:10.1136/bmj.39489.470347.AD

32. English M, Opiyo N. Getting to grips with GRADE-perspective from a low-income setting. J Clin Epidemiol. 2011;64(7):708-710. doi:10.1016/j.jclinepi.2010.07.016

33. Adams HP Jr, Brott TG, Crowell RM, et al. Guidelines for the management of patients with acute ischemic stroke: a statement for healthcare professionals from a special writing group of the Stroke Council, American Heart Association. Circulation. 1994; 90: 1588-1601. 
40 Scoping Review of Existing Stroke Guidelines; Argument for a Value-Added Change

34. Wolpert SM, Bruckmann H, Greenlee R, Wechsler L, Pessin MS, del Zoppo GJ, rtPA Acute Stroke Study Group. Neuroradiologic evaluation of patients with acute stroke treated with recombinant tissue plasminogen activator. AJNR. 1993;14:3-13.

35. Adams HP, Brott TG, Furlan AJ, Gomez CR, Grotta J, Helgason CM, Kwiatkowski T, Lyden PD, Marler JR, Torner J, Feinberg W, Mayberg M, Thies W. Guidelines for thrombolytic therapy for acute stroke: a supplement to the guidelines for the management of patients with acute ischemic stroke: a statement for healthcare professionals from a Special Writing Group of the Stroke Council, American Heart Association.Circulation. 1996;

36. Norris JW, Buchan A, Cote R, Hachinski V, Phillips SJ, Shuaib A, Silver F, Simard D, Teal P. Canadian guidelines for intravenous thrombolytic treatment in acute stroke. A consensus statement of the Canadian Stroke Consortium. Can J Neurol Sci. 1998 Aug;25(3):257-9. doi: 10.1017/s0317167100034120. PMID: 9706731.

37. National Institute of Neurological Disorders and Stroke rt-PA Stroke Study Group. Tissue plasminogen activator for acute ischemic stroke. N Engl J Med. 1995 Dec 14;333(24):1581-7. doi: 10.1056/NEJM199512143332401. PMID: 7477192.

38. Hacke W, Kaste M, Bluhmki E, Brozman M, Dávalos A, Guidetti D, Larrue V, Lees KR, Medeghri Z, Machnig T, Schneider D, von Kummer R, Wahlgren N, Toni D; ECASS Investigators. Thrombolysis with alteplase 3 to 4.5 hours after acute ischemic stroke. N Engl J Med. 2008 Sep 25;359(13):1317-29. doi: 10.1056/NEJMoa0804656. PMID: 18815396.

39. Jauch EC, Saver JL, Adams HP Jr, Bruno A, Connors JJ, Demaerschalk BM, Khatri P, McMullan PW Jr, Qureshi AI, Rosenfield K, Scott PA, Summers DR, Wang DZ, Wintermark M, Yonas H; American Heart Association Stroke Council; Council on 
41 Scoping Review of Existing Stroke Guidelines; Argument for a Value-Added Change

Cardiovascular Nursing; Council on Peripheral Vascular Disease; Council on Clinical Cardiology. Guidelines for the early management of patients with acute ischemic stroke: a guideline for healthcare professionals from the American Heart Association/American Stroke Association. Stroke. 2013 Mar;44(3):870-947. doi:

10.1161/STR.0b013e318284056a. Epub 2013 Jan 31. PMID: 23370205.

40. Yamaguchi T, Mori E, Minematsu K, Nakagawara J, Hashi K, Saito I, Shinohara Y; Japan Alteplase Clinical Trial (J-ACT) Group. Alteplase at $0.6 \mathrm{mg} / \mathrm{kg}$ for acute ischemic stroke within 3 hours of onset: Japan Alteplase Clinical Trial (J-ACT). Stroke. 2006 Jul;37(7):1810-5. doi: 10.1161/01.STR.0000227191.01792.e3. Epub 2006 Jun 8. PMID: 16763187.

41. Fransen PS, Beumer D, Berkhemer OA, van den Berg LA, Lingsma H, van der Lugt A, van Zwam WH, van Oostenbrugge RJ, Roos YB, Majoie CB, Dippel DW; MR CLEAN Investigators. MR CLEAN, a multicenter randomized clinical trial of endovascular treatment for acute ischemic stroke in the Netherlands: study protocol for a randomized controlled trial. Trials. 2014 Sep 1;15:343. doi: 10.1186/1745-6215-15-343. PMID: 25179366; PMCID: PMC4162915.

42. Goyal M, Demchuk AM, Menon BK, Eesa M, Rempel JL, Thornton J, Roy D, Jovin TG, Willinsky RA, Sapkota BL, Dowlatshahi D, Frei DF, Kamal NR, Montanera WJ, Poppe AY, Ryckborst KJ, Silver FL, Shuaib A, Tampieri D, Williams D, Bang OY, Baxter BW, Burns PA, Choe H, Heo JH, Holmstedt CA, Jankowitz B, Kelly M, Linares G, Mandzia JL, Shankar J, Sohn SI, Swartz RH, Barber PA, Coutts SB, Smith EE, Morrish WF, Weill A, Subramaniam S, Mitha AP, Wong JH, Lowerison MW, Sajobi TT, Hill MD; ESCAPE Trial Investigators. Randomized assessment of rapid 
42 Scoping Review of Existing Stroke Guidelines; Argument for a Value-Added Change

endovascular treatment of ischemic stroke. N Engl J Med. 2015 Mar 12;372(11):101930. doi: 10.1056/NEJMoa1414905. Epub 2015 Feb 11. PMID: 25671798.

43. Campbell BC, Mitchell PJ, Kleinig TJ, Dewey HM, Churilov L, Yassi N, Yan B, Dowling RJ, Parsons MW, Oxley TJ, Wu TY, Brooks M, Simpson MA, Miteff F, Levi CR, Krause M, Harrington TJ, Faulder KC, Steinfort BS, Priglinger M, Ang T, Scroop R, Barber PA, McGuinness B, Wijeratne T, Phan TG, Chong W, Chandra RV, Bladin CF, Badve M, Rice H, de Villiers L, Ma H, Desmond PM, Donnan GA, Davis SM; EXTEND-IA Investigators. Endovascular therapy for ischemic stroke with perfusionimaging selection. N Engl J Med. 2015 Mar 12;372(11):1009-18. doi: 10.1056/NEJMoa1414792. Epub 2015 Feb 11. PMID: 25671797.

44. Saver JL, Jahan R, Levy EI, et al. . Solitaire flow restoration device versus the Merci Retriever in patients with acute ischaemic stroke (SWIFT): a randomised, parallelgroup, non-inferiority trial. Lancet2012;380:1241-9.10.1016/S0140-6736(12)61384-1

45. Dávalos A, Cobo E, Molina CA, Chamorro A, de Miquel MA, Román LS, Serena J, López-Cancio E, Ribó M, Millán M, Urra X, Cardona P, Tomasello A, Castaño C, Blasco J, Aja L, Rubiera M, Gomis M, Renú A, Lara B, Martí-Fàbregas J, Jankowitz B, Cerdà N, Jovin TG; REVASCAT Trial Investigators. Safety and efficacy of thrombectomy in acute ischaemic stroke (REVASCAT): 1-year follow-up of a randomised open-label trial. Lancet Neurol. 2017 May;16(5):369-376. doi: 10.1016/S1474-4422(17)30047-9. Epub 2017 Mar 16. PMID: 28318984.

46. Nogueira RG, Jadhav AP, Haussen DC, Bonafe A, Budzik RF, Bhuva P, Yavagal DR, Ribo M, Cognard C, Hanel RA, Sila CA, Hassan AE, Millan M, Levy EI, Mitchell P, Chen M, English JD, Shah QA, Silver FL, Pereira VM, Mehta BP, Baxter BW, Abraham MG, Cardona P, Veznedaroglu E, Hellinger FR, Feng L, Kirmani JF, Lopes 
43 Scoping Review of Existing Stroke Guidelines; Argument for a Value-Added Change

DK, Jankowitz BT, Frankel MR, Costalat V, Vora NA, Yoo AJ, Malik AM, Furlan AJ,

Rubiera M, Aghaebrahim A, Olivot JM, Tekle WG, Shields R, Graves T, Lewis RJ,

Smith WS, Liebeskind DS, Saver JL, Jovin TG; DAWN Trial Investigators.

Thrombectomy 6 to 24 Hours after Stroke with a Mismatch between Deficit and Infarct.

N Engl J Med. 2018 Jan 4;378(1):11-21. doi: 10.1056/NEJMoa1706442. Epub 2017

Nov 11. PMID: 29129157.

47. Albers GW, Marks MP, Kemp S, Christensen S, Tsai JP, Ortega-Gutierrez S, McTaggart RA, Torbey MT, Kim-Tenser M, Leslie-Mazwi T, Sarraj A, Kasner SE, Ansari SA, Yeatts SD, Hamilton S, Mlynash M, Heit JJ, Zaharchuk G, Kim S, Carrozzella J, Palesch YY, Demchuk AM, Bammer R, Lavori PW, Broderick JP, Lansberg MG; DEFUSE 3 Investigators. Thrombectomy for Stroke at 6 to 16 Hours with Selection by Perfusion Imaging. N Engl J Med. 2018 Feb 22;378(8):708-718. doi: 10.1056/NEJMoa1713973. Epub 2018 Jan 24. PMID: 29364767; PMCID: PMC6590673.

48. Jakovljevic, M., Potapchik, E., Popovich, L., Barik, D., \& Getzen, T. E. (2017). Evolving health expenditure landscape of the BRICS nations and projections to 2025. Health economics, 26(7), 844-852. https://onlinelibrary.wiley.com/doi/abs/10.1002/hec.3406

49. Chimatiro GL, Rhoda AJ. Scoping review of acute stroke care management and rehabilitation in low and middle-income countries. BMC Health Serv Res. 2019;19(1):789. Published 2019 Nov 4. doi:10.1186/s12913-019-4654-

50. Badachi S, Mathew T, Prabhu A, Nadig R, Sarma GR. Hurdles in stroke thrombolysis: Experience from 100 consecutive ischemic stroke patients. Ann Indian Acad Neurol. 2015;18(4):415-418. doi:10.4103/0972-2327.165460 
44 Scoping Review of Existing Stroke Guidelines; Argument for a Value-Added Change

51. Ranković, A., Rančić, N., Jovanović, M., Ivanović, M., Gajović, O., Lazić, Z., \& Jakovljević, M. (2013). Impact of imaging diagnostics on the budget: are we spending too much?. Vojnosanitetski pregled, 70(7), 709-711.

52. Jakovljevic, M., Vukovic, M., Chen, C. C., Antunovic, M., Dragojevic-Simic, V., Velickovic-Radovanovic, R., ... \& Yamada, T. (2016). Do health reforms impact cost consciousness of Health care professionals? Results from a nation-wide survey in the Balkans. Balkan Medical Journal, 33(1), 8. https://www.ncbi.nlm.nih.gov/pmc/articles/PMC4767315/

53. Tsang ACO, Yang IH, Orru E, Nguyen QA, Pamatmat RV, Medhi G, Wan Y, Huang S. Overview of endovascular thrombectomy accessibility gap for acute ischemic stroke in Asia: A multi-national survey. Int J Stroke. 2020 Jul;15(5):516-520. doi: 10.1177/1747493019881345. Epub 2019 Oct 3. PMID: 31581928.

54. Zaidi SF, Shawver J, Espinosa Morales A, Salahuddin H, Tietjen G, Lindstrom D, Parquette B, Adams A, Korsnack A, Jumaa MA. Stroke care: initial data from a countybased bypass protocol for patients with acute stroke. J Neurointerv Surg. 2017 Jul;9(7):631-635. doi: 10.1136/neurintsurg-2016-012476. Epub 2016 Jun 24. PMID: 27342763; PMCID: PMC5520240.

55. Huff JS. Stroke mimics and chameleons. Emerg Med Clin North Am. 2002 Aug;20(3):583-95. doi: 10.1016/s0733-8627(02)00012-3. PMID: 12379962.

56. Ohshita T, Imamura E, Nomura E, Wakabayashi S, Kajikawa H, Matsumoto M. Hypoglycemia with focal neurological signs as stroke mimic: Clinical and neuroradiological characteristics. J Neurol Sci. 2015;353(1-2):98-101. doi: 10.1016/j.jns.2015.04.015. Epub 2015 Apr 17. PMID: 25912175. 
45 Scoping Review of Existing Stroke Guidelines; Argument for a Value-Added Change

57. Miedema I, Luijckx GJ, Brouns R, De Keyser J, Uyttenboogaart M. Admission hyperglycemia and outcome after intravenous thrombolysis: is there a difference among the stroke-subtypes?. BMC Neurol. 2016;16:104. Published 2016 Jul 15. doi:10.1186/s12883-016-0617-0

58. Braga GP, Gonçalves RS, Minicucci MF, Bazan R, Zornoff LAM. Strain pattern and Twave alterations are predictors of mortality and poor neurologic outcome following stroke. Clin Cardiol. 2020 Jun;43(6):568-573. doi: 10.1002/clc.23348. Epub 2020 Feb 22. PMID: 32087617; PMCID: PMC7298998.

59. Lazar J, Busch D, Wirkowski E, Clark LT, Salciccioli L. Changes in QT dispersion after thrombolysis for stroke. Int J Cardiol. 2008 Apr 10;125(2):258-62. doi: 10.1016/j.ijcard.2007.03.114. Epub 2007 May 16. PMID: 17509702.

60. Wu F, Cao W, Ling Y, Yang L, Cheng X, Dong Q. The predictive role of electrocardiographic abnormalities in ischemic stroke patients with intravenous thrombolysis. Int J Cardiol Heart Vessel. 2014 Jul 9;4:81-83. doi: 10.1016/j.ijchv.2014.06.010. PMID: 29450185; PMCID: PMC5801448

61. Alqahtani F, Aljohani S, Tarabishy A, Busu T, Adcock A, Alkhouli M. Incidence and Outcomes of Myocardial Infarction in Patients Admitted With Acute Ischemic Stroke. Stroke. 2017 Nov;48(11):2931-2938. doi: 10.1161/STROKEAHA.117.018408. Epub 2017 Oct 10. PMID: 29018137.

62. Chiu A, Shen Q, Cheuk G, Cordato D, Chan DK. Establishment of a stroke unit in a district hospital: review of experience. Intern Med J. 2007 Feb;37(2):73-8. doi: 10.1111/j.1445-5994.2007.01235.x. PMID: 17229248. 
46 Scoping Review of Existing Stroke Guidelines; Argument for a Value-Added Change

63. Chen LK, McClaran J, Buchan AM. Impact of acute stroke unit on hospital length of stay. Arch Gerontol Geriatr. 2009 Jul-Aug;49(1):e12-5. doi: 10.1016/j.archger.2008.07.008. Epub 2008 Sep 11. PMID: 18789547.

64. Jakovljevic, M., \& Getzen, T. E. (2016). Growth of global health spending share in low and middle income countries. Frontiers in pharmacology, 7, 21. https://www.frontiersin.org/articles/10.3389/fphar.2016.00021/full

65. Bryer A, Wasserman S. Thrombolysis for acute ischemic stroke in South Africa. Int J Stroke. 2013 Oct;8 Suppl A100:112-3. doi: 10.1111/ijs.12059. Epub 2013 May 22. PMID: 23692573.

66. Wasserman S, Bryer A. Early outcomes of thrombolysis for acute ischaemic stroke in a South African tertiary care centre. S Afr Med J. 2012 May 23;102(6):541-4. doi: 10.7196/samj.5403. PMID: 22668959.

67. Waltimo T, Haapaniemi E, Surakka IL, Melkas S, Sairanen T, Sibolt G, Tatlisumak T, Strbian D. Post-thrombolytic blood pressure and symptomatic intracerebral hemorrhage. Eur J Neurol. 2016 Dec;23(12):1757-1762. doi: 10.1111/ene.13118. Epub 2016 Aug 16. PMID: 27529662

68. Li C, Wang Y, Chen Y, Zhang C, Dong Z, Zhang S, Tong Y, Lv Z, Tong X, Wang J, Zhang P. Optimal blood pressure levels in patients undergoing intravenous thrombolysis for AIS. Minerva Med. 2015 Oct;106(5):255-258. Epub 2015 Sep 22. PMID: 26393383. 69. Wu L, Huang X, Wu D, Zhao W, Wu C, Che R, Zhang Z, Jiang F, Bian T, Yang T, Dong K, Zhang Q, Yu Z, Ma Q, Song H, Ding Y, Ji X. Relationship between PostThrombolysis Blood Pressure and Outcome in Acute Ischemic Stroke Patients Undergoing Thrombolysis Therapy. J Stroke Cerebrovasc Dis. 2017 Oct;26(10):2279- 
47 Scoping Review of Existing Stroke Guidelines; Argument for a Value-Added Change

2286. doi: 10.1016/j.jstrokecerebrovasdis.2017.05.011. Epub 2017 Jun 1. PMID: 28579505.

70. Anderson CS, Huang Y, Lindley RI, Chen X, Arima H, Chen G, Li Q, Billot L, Delcourt C, Bath PM, Broderick JP, Demchuk AM, Donnan GA, Durham AC, Lavados PM, Lee TH, Levi C, Martins SO, Olavarria VV, Pandian JD, Parsons MW, PontesNeto OM, Ricci S, Sato S, Sharma VK, Silva F, Song L, Thang NH, Wardlaw JM, Wang JG, Wang X, Woodward M, Chalmers J, Robinson TG; ENCHANTED Investigators and Coordinators. Intensive blood pressure reduction with intravenous thrombolysis therapy for acute ischaemic stroke (ENCHANTED): an international, randomised, open-label, blinded-endpoint, phase 3 trial. Lancet. 2019 Mar 2;393(10174):877-888. doi: 10.1016/S0140-6736(19)30038-8. Epub 2019 Feb 7. PMID: 30739745.

71. Mori E, Minematsu K, Nakagawara J, Yamaguchi T, Sasaki M, Hirano T; Japan Alteplase Clinical Trial II Group. Effects of $0.6 \mathrm{mg} / \mathrm{kg}$ intravenous alteplase on vascular and clinical outcomes in middle cerebral artery occlusion: Japan Alteplase Clinical Trial II (J-ACT II). Stroke. 2010 Mar;41(3):461-5. doi: 10.1161/STROKEAHA.109.573477. Epub 2010 Jan 14. PMID: 20075341.

72. Jakovljevic, M. B., Nakazono, S., \& Ogura, S. (2014). Contemporary generic market in Japan-key conditions to successful evolution. Expert review of pharmacoeconomics \& outcomes research, 14(2), 181-194. https://www.tandfonline.com/doi/abs/10.1586/14737167.2014.881254

73. Koga M, Yamamoto H, Inoue M, Asakura K, Aoki J, Hamasaki T, Kanzawa T, Kondo R, Ohtaki M, Itabashi R, Kamiyama K, Iwama T, Nakase T, Yakushiji Y, Igarashi S, Nagakane Y, Takizawa S, Okada Y, Doijiri R, Tsujino A, Ito Y, Ohnishi H, Inoue T, Takagi Y, Hasegawa Y, Shiokawa Y, Sakai N, Osaki M, Uesaka Y, Yoshimura S, 
48 Scoping Review of Existing Stroke Guidelines; Argument for a Value-Added Change

Urabe T, Ueda T, Ihara M, Kitazono T, Sasaki M, Oita A, Yoshimura S, Fukuda-Doi M,

Miwa K, Kimura K, Minematsu K, Toyoda K; THAWS Trial Investigators.

Thrombolysis With Alteplase at $0.6 \mathrm{mg} / \mathrm{kg}$ for Stroke With Unknown Time of Onset: A Randomized Controlled Trial. Stroke. 2020 May;51(5):1530-1538. doi:

10.1161/STROKEAHA.119.028127. Epub 2020 Apr 6. PMID: 32248771; PMCID: PMC7185058.

74. Ueshima S, Matsuo O. The differences in thrombolytic effects of administrated recombinant t-PA between Japanese and Caucasians. Thromb Haemost. 2002;87:544546

75. Thomalla G, Simonsen CZ, Boutitie F, Andersen G, Berthezene Y, Cheng B, Cheripelli B, Cho TH, Fazekas F, Fiehler J, Ford I, Galinovic I, Gellissen S, Golsari A, Gregori J, Günther M, Guibernau J, Häusler KG, Hennerici M, Kemmling A, Marstrand J, Modrau B, Neeb L, Perez de la Ossa N, Puig J, Ringleb P, Roy P, Scheel E, Schonewille W, Serena J, Sunaert S, Villringer K, Wouters A, Thijs V, Ebinger M, Endres M, Fiebach JB, Lemmens R, Muir KW, Nighoghossian N, Pedraza S, Gerloff C; WAKE-UP Investigators. MRI-Guided Thrombolysis for Stroke with Unknown Time of Onset. N Engl J Med. 2018 Aug 16;379(7):611-622. doi: 10.1056/NEJMoa1804355. Epub 2018 May 16. PMID: 29766770.

76. Jakovljevic, M., Sugahara, T., Timofeyev, Y., \& Rancic, N. (2020). Predictors of (in) efficiencies of Healthcare Expenditure Among the Leading Asian EconomiesComparison of OECD and Non-OECD Nations. Risk Management and Healthcare Policy, 13, 2261. https://www.ncbi.nlm.nih.gov/pmc/articles/PMC7585857/

77. Khatib R, Arevalo YA, Berendsen MA, Prabhakaran S, Huffman MD. Presentation, Evaluation, Management, and Outcomes of Acute Stroke in Low- and Middle-Income 
49 Scoping Review of Existing Stroke Guidelines; Argument for a Value-Added Change

Countries: A Systematic Review and Meta-Analysis. Neuroepidemiology. 2018;51(12):104-112. doi:10.1159/000491442

78. Shrestha GS, Goffi A, Aryal D. Delivering neurocritical care in resource-challenged environments. Curr Opin Crit Care. 2016 Apr;22(2):100-5. doi:

10.1097/MCC.0000000000000285. PMID: 26828423.

79. Punchak M, Mukhopadhyay S, Sachdev S, Hung YC, Peeters S, Rattani A, Dewan M, Johnson WD, Park KB. Neurosurgical Care: Availability and Access in Low-Income and Middle-Income Countries. World Neurosurg. 2018 Apr;112:e240-e254. doi: 10.1016/j.wneu.2018.01.029. Epub 2018 Jan 8. PMID: 29325943.

80. Rudolfson N, Dewan MC, Park KB, Shrime MG, Meara JG, Alkire BC. The economic consequences of neurosurgical disease in low- and middle-income countries. J Neurosurg. 2018 May 1:1-8. doi: 10.3171/2017.12.JNS17281. Epub ahead of print. PMID: 29775144

81. Duncan PW, Horner RD, Reker DM, Samsa GP, Hoenig H, Hamilton B, LaClair BJ, Dudley TK. Adherence to postacute rehabilitation guidelines is associated with functional recovery in stroke. Stroke. 2002 Jan;33(1):167-77. doi: 10.1161/hs0102.101014. PMID: 11779907.

82. Miura S, Miyata R, Matsumoto S, Higashi T, Wakisaka Y, Ago T, Kitazono T, Iihara K, Shimodozono M. Quality Management Program of Stroke Rehabilitation Using Adherence to Guidelines: A Nationwide Initiative in Japan. J Stroke Cerebrovasc Dis. 2019 Sep;28(9):2434-2441. doi: 10.1016/j.jstrokecerebrovasdis.2019.06.028. Epub 2019 Jul 10. PMID: 31301984.

83. Jakovljevic, M. B., Nakazono, S., \& Ogura, S. (2014). Contemporary generic market in Japan-key conditions to successful evolution. Expert review of pharmacoeconomics \& 
50 Scoping Review of Existing Stroke Guidelines; Argument for a Value-Added Change

outcomes research, 14(2), 181-194.

https://www.tandfonline.com/doi/abs/10.1586/14737167.2014.881254

84. Hubbard IJ, Harris D, Kilkenny MF, Faux SG, Pollack MR, Cadilhac DA. Adherence to clinical guidelines improves patient outcomes in Australian audit of stroke rehabilitation practice. Arch Phys Med Rehabil. 2012 Jun;93(6):965-71. doi:

10.1016/j.apmr.2012.01.011. Epub 2012 Apr 4. PMID: 22480546.

85. Dee M, Lennon O, O'Sullivan C. A systematic review of physical rehabilitation interventions for stroke in low and lower-middle income countries. Disabil Rehabil. 2020 Feb;42(4):473-501. doi: 10.1080/09638288.2018.1501617. Epub 2018 Dec 3. PMID: 30508495.

86. Jakovljevic, M., Sugahara, T., Timofeyev, Y., \& Rancic, N. (2020). Predictors of (in) efficiencies of Healthcare Expenditure Among the Leading Asian EconomiesComparison of OECD and Non-OECD Nations. Risk Management and Healthcare Policy, 13, 2261. https://www.ncbi.nlm.nih.gov/pmc/articles/PMC7585857/

87. Langhorne P, Wu O, Rodgers H, Ashburn A, Bernhardt J. A Very Early Rehabilitation Trial after stroke (AVERT): a Phase III, multicentre, randomised controlled trial. Health Technol Assess. 2017 Sep;21(54):1-120. doi: 10.3310/hta21540. PMID: 28967376; PMCID: PMC5641820.

88. Herisson F, Godard S, Volteau C, Le Blanc E, Guillon B, Gaudron M; SEVEL study group. Early Sitting in Ischemic Stroke Patients (SEVEL): A Randomized Controlled Trial. PLoS One. 2016 Mar 29;11(3):e0149466. doi: 10.1371/journal.pone.0149466. PMID: 27023901; PMCID: PMC4811411. 
51 Scoping Review of Existing Stroke Guidelines; Argument for a Value-Added Change

89. Henke C, Foerch C, Lapa S. Early Screening Parameters for Dysphagia in Acute Ischemic Stroke. Cerebrovasc Dis. 2017;44(5-6):285-290. doi: 10.1159/000480123. Epub 2017 Sep 14. PMID: 28903096.

90. Abubakar SA, Jamoh BY. Dysphagia following acute stroke and its effect on short-term outcome. Niger Postgrad Med J. 2017 Jul-Sep;24(3):182-186. doi: 10.4103/npmj.npmj_96_17. PMID: 29082909.

91. Zhang D, Li F, Li X, Du G. Effect of Intermittent Pneumatic Compression on Preventing Deep Vein Thrombosis Among Stroke Patients: A Systematic Review and Meta-Analysis. Worldviews Evid Based Nurs. 2018 Jun;15(3):189-196. doi: 10.1111/wvn.12288. Epub 2018 May 5. PMID: 29729658.

92. Reshetnikov, V., Arsentyev, E., Bolevich, S., Timofeyev, Y., \& Jakovljević, M. (2019). Analysis of the financing of Russian health care over the past 100 years. https://www.mdpi.com/1660-4601/16/10/1848/htm

93. Lenzi GL, Altieri M, Maestrini I. Post-stroke depression. Rev Neurol (Paris). 2008 Oct;164(10):837-40. doi: 10.1016/j.neurol.2008.07.010. Epub 2008 Sep 3. PMID: 18771785.

94. Ojagbemi A, Akinyemi J, Owolabi M, Akinyemi R, Arulogun O, Gebregziabher M, Akpa O, Olaniyan O, Salako B, Ovbiagele B. Predictors and prognoses of new onset post-stroke anxiety at one year in black Africans. J Stroke Cerebrovasc Dis. 2020 Sep;29(9):105082. doi: 10.1016/j.jstrokecerebrovasdis.2020.105082. Epub 2020 Jul 3. PMID: 32807479. 
52 Scoping Review of Existing Stroke Guidelines; Argument for a Value-Added Change

95. Sarfo FS, Nichols M, Qanungo S, Teklehaimanot A, Singh A, Mensah N, Saulson R, Gebregziabher M, Ezinne U, Owolabi M, Jenkins C, Ovbiagele B. Stroke-related stigma among West Africans: Patterns and predictors. J Neurol Sci. 2017 Apr 15;375:270-274. doi: 10.1016/j.jns.2017.02.018. Epub 2017 Feb 9. PMID: 28320146; PMCID: PMC5364027.

96. Simpkins AN, Janowski M, Oz HS, Roberts J, Bix G, Doré S, Stowe AM. Biomarker Application for Precision Medicine in Stroke. Transl Stroke Res. 2020 Aug;11(4):615627. doi: 10.1007/s12975-019-00762-3. Epub 2019 Dec 18. PMID: 31848851; PMCID: PMC7299765.

97. Zhang J, Ren Q, Song Y, He M, Zeng Y, Liu Z, Xu J. Prognostic role of neutrophillymphocyte ratio in patients with acute ischemic stroke. Medicine (Baltimore). 2017 Nov;96(45):e8624. doi: 10.1097/MD.0000000000008624. PMID: 29137097; PMCID: PMC5690790.

98. Zhang R, Wu X, Hu W, Zhao L, Zhao S, Zhang J, Chu Z, Xu Y. Neutrophil-tolymphocyte ratio predicts hemorrhagic transformation in ischemic stroke: A metaanalysis. Brain Behav. 2019 Sep;9(9):e01382. doi: 10.1002/brb3.1382. Epub 2019 Aug 20. PMID: 31429525; PMCID: PMC6749596.

99. Wan J, Wang X, Zhen Y, Chen X, Yao P, Liu W, Lu E, Du Y, Liu H, Zhao S. The predictive role of the neutrophil-lymphocyte ratio in the prognosis of adult patients with stroke. Chin Neurosurg J. 2020 Jul 1;6:22. doi: 10.1186/s41016-020-00201-5. PMID: 32922951 ; PMCID: PMC7398197.

100. Vuong LN, Thulasi P, Biousse V, Garza P, Wright DW, Newman NJ, Bruce BB. Ocular fundus photography of patients with focal neurologic deficits in an emergency department. Neurology. 2015 Jul 21;85(3):256-62. doi: 
53 Scoping Review of Existing Stroke Guidelines; Argument for a Value-Added Change

10.1212/WNL.0000000000001759. Epub 2015 Jun 24. PMID: 26109710; PMCID: PMC4516298.

101. Cheung CY, Ikram MK, Chen C, Wong TY. Imaging retina to study dementia and stroke. Prog Retin Eye Res. 2017 Mar;57:89-107. doi:

10.1016/j.preteyeres.2017.01.001. Epub 2017 Jan 3. PMID: 28057562.

102. Cheung CY, Chen C, Wong TY. Ocular Fundus Photography as a Tool to Study Stroke and Dementia. Semin Neurol. 2015 Oct;35(5):481-90. doi: 10.1055/s-00351563570. Epub 2015 Oct 6. PMID: 26444393.

103. Jakovljevic, M., Timofeyev, Y., Ranabhat, C. L., Fernandes, P. O., Teixeira, J. P., Rancic, N., \& Reshetnikov, V. (2020). Real GDP growth rates and healthcare spendingcomparison between the G7 and the EM7 countries. Globalization and Health, 16(1), 113. https://globalizationandhealth.biomedcentral.com/articles/10.1186/s12992-02000590-3

104. Wijeratne T, Crewther S. COVID-19 and long-term neurological problems: Challenges ahead with Post-COVID-19 Neurological Syndrome. Aust J Gen Pract. 2021 Jan 12;50. doi: 10.31128/AJGP-COVID-43. Epub ahead of print. PMID: 33543150.

105. Wijeratne T, Gillard Crewther S, Sales C, Karimi L. COVID-19 Pathophysiology Predicts That Ischemic Stroke Occurrence Is an Expectation, Not an Exception-A Systematic Review. Frontiers in Neurology. 2021;11(1759).

106. Wijeratne T, Crewther S. Post-COVID 19 Neurological Syndrome (PCNS); a novel syndrome with challenges for the global neurology community. J Neurol Sci. 2020;419:117179. 
54 Scoping Review of Existing Stroke Guidelines; Argument for a Value-Added Change

107. Slavich GM, Auerbach, R. P. Stress and its sequelae:Depression,suicide,inflammation, and physical illness. J.M.Hooley JNB, editor. Washington DC American Psychological Association 2018.

108. Louveau A, Plog BA, Antila S, Alitalo K, Nedergaard M, Kipnis J. Understanding the functions and relationships of the glymphatic system and meningeal lymphatics. The Journal of clinical investigation. 2017;127(9):3210-9.

109. Johnson CO, Nguyen M, Roth GA, Nichols E, Alam T, Abate D, et al. Global, regional, and national burden of stroke, 1990\&\#x2013;2016: a systematic analysis for the Global Burden of Disease Study 2016. The Lancet Neurology. 2019;18(5):439-58.

110. Mellon L, Brewer L, Hall P, Horgan F, Williams D, Hickey A, et al. Cognitive impairment six months after ischaemic stroke: a profile from the ASPIRE-S study. BMC Neurology. 2015;15(1):31.

111. Knapp P, Dunn-Roberts A, Sahib N, Cook L, Astin F, Kontou E, et al. Frequency of anxiety after stroke: An updated systematic review and meta-analysis of observational studies. International Journal of Stroke. 2020;15(3):244-55.

112. Liampas A, Velidakis N, Georgiou T, Vadalouca A, Varrassi G, Hadjigeorgiou GM, Tsivgoulis G, Zis P. Prevalence and Management Challenges in Central Post-Stroke Neuropathic Pain: A Systematic Review and Meta-analysis. Adv Ther. 2020 Jul;37(7):3278-3291. doi: 10.1007/s12325-020-01388-w. Epub 2020 May 23. PMID: 32451951; PMCID: PMC7467424.

113. Medeiros GC, Roy D, Kontos N, Beach SR. Post-stroke depression: A 2020 updated review. Gen Hosp Psychiatry. 2020;66:70-80. 
55 Scoping Review of Existing Stroke Guidelines; Argument for a Value-Added Change

114. Pascoe MC, Crewther SG, Carey LM, Crewther DP. Inflammation and depression: why poststroke depression may be the norm and not the exception. Int J Stroke. 2011;6(2):128-35.

115. Acciarresi M, Bogousslavsky J, Paciaroni M. Post-stroke fatigue: epidemiology, clinical characteristics and treatment. Eur Neurol. 2014;72(5-6):255-61.

116. Jakovljevic, M., Timofeyev, Y., Ranabhat, C. L., Fernandes, P. O., Teixeira, J. P., Rancic, N., \& Reshetnikov, V. (2020). Real GDP growth rates and healthcare spendingcomparison between the G7 and the EM7 countries. Globalization and Health, 16(1), 113. https://globalizationandhealth.biomedcentral.com/articles/10.1186/s12992-02000590-3

117. Paciaroni M, Acciarresi M. Poststroke Fatigue. Stroke. 2019;50(7):1927-33. 